\title{
Sedimentology of a Middle Jurassic base-of-slope environment, Cutri Formation, Mallorca
}

\author{
S. Kettle ${ }^{1}$ \\ ${ }^{1}$ 6, Delves Avenue, Tunbridge Wells, TN2 5DR, United Kingdom. \\ e-mail address: skettle@outlook.com
}

Received: 14 October 2015 / Accepted: 15 April 2016 / Available online: 30 April 2016

\begin{abstract}
The Cutri Formation's type location exposed in the NW of Mallorca, Spain, has previously been described and further interpreted as a base-of-slope carbonate apron. Incorporating new field and laboratory analysis this paper enhances this interpretation. From this analysis, it can be shown without reasonable doubt that the Cutri Formation was deposited in a carbonate base-of-slope environment on the palaeowindward side of a Mid-Jurassic Tethyan platform. Key evidence such as laterally extensive exposures, abundant deposits of calciturbidtes and debris flows amongst hemipelagic deposits strongly support this interpretation.
\end{abstract}

Keywords: calcilturbidite, debrite, Bositra, Jurassic, Mallorca, base-of-slope apron

Resumen

La Formación Cutri, en su localidad tipo en el noroeste de Mallorca (España), ha sido previamente interpretada como un posible prisma de talud carbonático. Esta interpretación es ratificada y pormenorizada en este trabajo con la incorporación de nuevos datos de campo y de laboratorio. El análisis realizado muestra que la Formación Cutri se depositó en la base del talud, en el lado de un ambiente carbonato de base de la pendiente a barlovento de una plataforma carbonatada tetisiana del Jurásico Medio. Esta interpretación está apoyada por extensos afloramientos de gran continuidad lateral, abundantes niveles de calciturbidtas y debris-flows entre los depósitos hemipelágicos.

Palabras clave: calcilturbidita, debrita, Bositra, Jurásico, Mallorca, prisma de base de talud carbonático

\section{Introduction}

Resedimented carbonates interbedded with basinal facies are described in Tethyan Middle Jurassic carbonate stratigraphy, as demonstrated by the Vajont limestone (Bosellini et al., 1981), Jabalcuz Formation (Ruiz-Ortiz, 1982) and Hawasina complex (Blechschmidt et al., 2004)). Carbonate gravity flow deposits are generally less studied than their siliciclastic counterparts. This study therefore intends to contribute to the collection of detailed sedimentological investigations.

Since the Early Jurassic the Balearic Islands have lain to the east of the Iberian massif as part of an extensive carbonate platform (e.g. Ziegler, 1990). From the late-Early Jurassic the area became more tectonically active and formed a basinand-platform topography, due to extensional tectonics as- sociated with the expansion of the Tethys Ocean westwards (Vera, 2004). Throughout Middle-Upper Jurassic an extensional pelagic basin of numerous horst blocks, capped by carbonate platforms with adjacent graben, dominated the area. A shallow platform developed during Middle-Late Jurassic and today this crops-out in the Sierra de Levante area of Mallorca.

Based on laterally extensive outcrops, this study builds on previous work carried out on the sedimentology of Jurassic carbonate deposits found on the island of Mallorca (Fig. 1). First described by Bourroilh (1973) and later reviewed by Barnolas and Simo (1987), Álvaro et al. (1989), and Abbots (1989) the Cúber Formation, Puig d'en Paré Formation and Cutri Formation represent a succession of continually deepening carbonate slope to basinal environments where a 

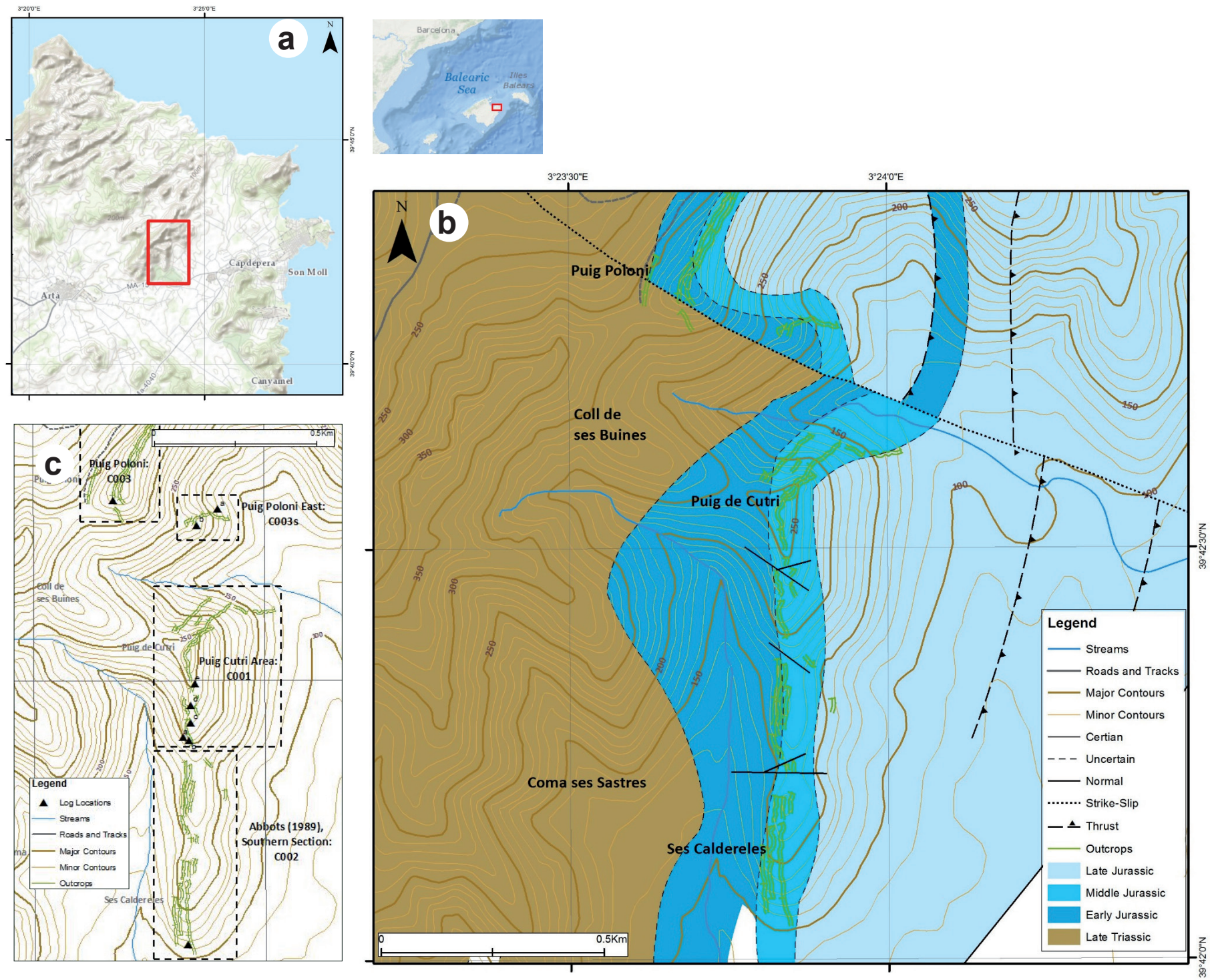

Fig. 1.- a) Location Map of study area (ESRI Topography Basemap and insert map ESRI Ocean Basemap). Maps are displayed in EPSG code: 23031. b) Geology map derived from IGME WMS database (2011). Topography based on CNIG (División 672-IV Artá). Map is displayed in EPSG code: 23031. c) Location names with logging locations names and locations. Triangles indicate individual start log locations (sedimentary logs are presented as composite). Topography based on CNIG (División 672-IV Artá) and map is displayed in EPSG code: 23031.

base-of-slope apron is interpreted to have formed during the Middle Jurassic.

This study incorporates new field and laboratory analysis which enhances this interpretation. From this analysis, it can be shown without reasonable doubt that the Cutri Formation was deposited in a carbonate base-of-slope environment on the palaeowindward side of a Mid-Jurassic Tethyan platform. Key evidence such as laterally extensive exposures, abundant deposits of calciturbidtes and debris flows amongst hemipelagic deposits strongly support this interpretation.

\section{Geological Setting}

The investigated strata are located in well-exposed outcrops found underfoot and as cliffs forming part of the Sierra de Levante that spans Mallorca from the NE to the SW. The area of interest is termed the Puig Cutri-Puig de ses Fites and is located NE of Artá and NW of Capdepera (Fig. 1a).

This area forms a distinctive N-S $2 \mathrm{~km}$ long ridge with some cliffs reaching heights of 30 metres. The outcrops are constrained by a NW-ESE normal fault to the north and a NE-SW normal fault to the south east (Fig. 1b). The outcrops are additionally dissected by NE-SW normal and strike-slip faults, which progressively downthrow the section to the south.

\subsection{Palaeogeography}

During the Middle Jurassic, the Iberian micro-plate was located between latitude $25^{\circ} \mathrm{N}$ and $35^{\circ} \mathrm{N}$ (Vera, 1998; Aurell et al., 2000; Golonka, 2007; Fig. 2). It was separated from the larger European plate to the NE by a fault-bounded trough 


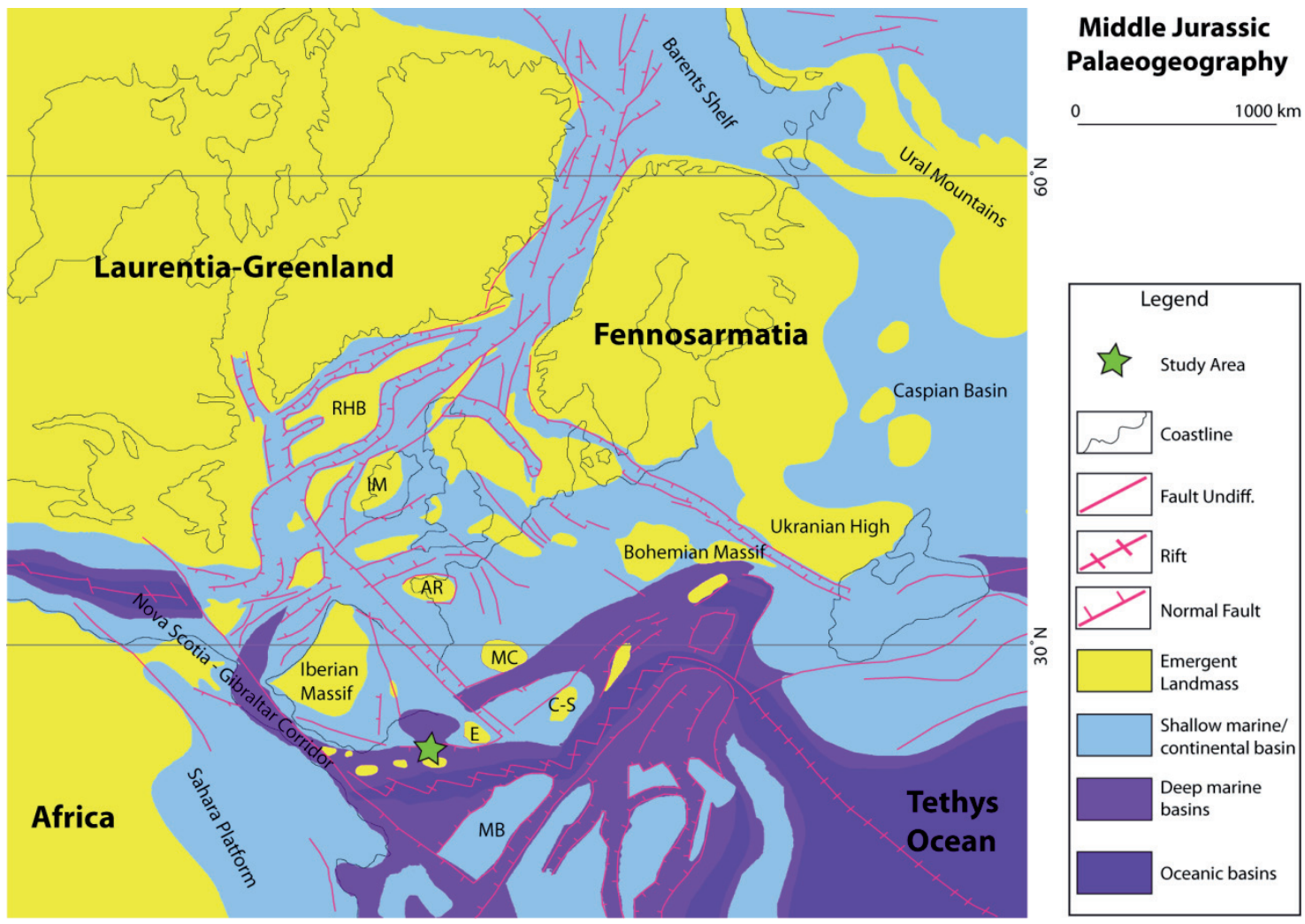

Fig. 2.- Palaeogeography of the Iberian Massif during the Middle Jurassic. The opening Atlantic and Neotethys during Middle Jurassic led to a new NW-SE seaway. Carbonate platforms lined the newly created oceans, with smaller platform fragments forming isolated carbonate platforms in their own right within the Neotethys (AR- Ammorican Massif, C-S- Corsica-Sardinia High, E- Ebro Massif, IM- Irish Massif, MB- Mesomediterranean block, MC- Massif Central, RHB- Rockall-Hatton block). Adapted from Colom and Escandell, 1962; Dercourt et al., 1986 ; Ziegler, 1990; Puga et al., 1993; Aurell et al., 2000; Vera, 1998; Olóriz, 2000; Golonka, 2007; Martin-Rojas et al., 2009.

corresponding to the early rifting of the Bay of Biscay (Aurell et al., 2000). To the NW it was separated from the LaurentiaGreenland Plate by an epicontinential sea with a graben and horst structure, which would eventually become the palaeogeographical connection between the northern and central Atlantic. To the south was the Maghrebian Trough adding to distention-related subsidence (Dercourt et al., 1986). The Iberian Massif was limited to the north by an additional zone of distention (Brunet, 1986), known as the Aquitaine Basin. Both this basin and the present Cantabrian margin were lined or occupied by submerged carbonate platforms until the end of the Mid-Jurassic (Curnelle et al., 1982). The Balearic Islands lay to the east of the Iberian massif as part of an extensive carbonate platform; forming basin-and-platform topography that stretched west to the South of Portugal where the Algarvian Shelf is now correlatable to the Pre-Betic domain (Garcia-Hernandez et al., 1980; Olóriz, 2000; Martin-Rojas et al., 2009).

The Ebro-Catalonian massif in the east was created from the assembly of the Calabrian, Alborán, Corsican, Sardinian and Briançonnais massifs (Michard et al., 2002). On its southern border, basinal sedimentation is indicated, succeeding that of the lowest Lower Jurassic platform. Fault breccias indicate that deepening was probably caused by limiting tilted blocks (Lagabrielle et al., 1984).

\subsection{The Balearic Islands}

During the Early Jurassic, Mallorca and Menorca were dominated by shallow carbonate platform deposits with no indication of deep water environments discovered throughout the two islands. The Balearic Islands appear to have become more tectonically active during the late Early Jurassic. This is suggested by the initiation of deep water deposition and the expansion of the shallow waters at the expense of the EbroCatalonian Massif (Colom and Escandell, 1962; Martin-Rojas et al., 2009).

During the Upper Jurassic this region consisted of numerous horst blocks capped by carbonate platforms with adjacent graben filled with pelagic sediments. Shallow-platform grainstones to argillaceous deeper carbonates accumulated on the passive margin shelves and isolated carbonate platforms of the north-western Neotethys. Extensional tectonics lead to the creation of offshore pelagic and hemipelagic troughs and swells where marl-limestone successions and condensed sequences were deposited on the classic representation of the Tethyan bathymetric topography (Bernoulli and Jenkyns, 1974).

During the Middle to Late Jurassic the Catalonian Massif northwest of the Balearic Islands subsided with the islands of Ibiza and Mallorca being covered by deeper water. Menorca, 


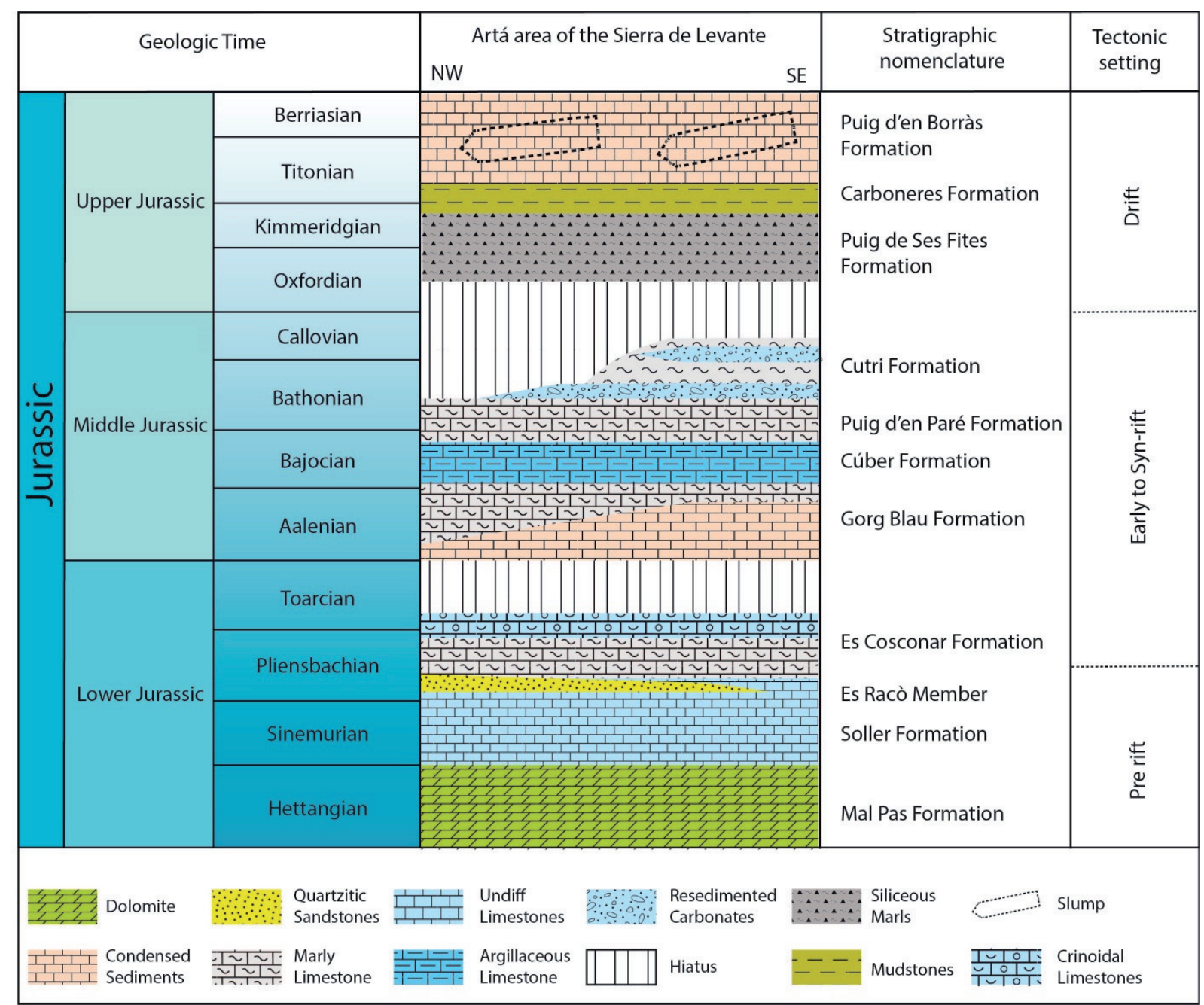

Fig. 3.- Chronostratigraphy of the Sierra de Levante during the Jurassic Period based on (Álvaro et al., 1989) and author's observations.

on the other hand maintained a shallow-platform environment.

\subsection{Jurassic Stratigraphy of the Sierra de Levante}

The oldest sediments in the area are in the Mal Pas Formation (Fig. 3), which consists of a $100 \mathrm{~m}$ thick dolomitic (partly brecciated) sequence that has been dated to the Hettangian (Aurell et al., 2000). Overlying this is the Sóller Formation, which represents a shallow carbonate platform sequence in its oldest part (Es Barraca Limestone) and dated as Sinemurian-early Pliensbachian. The Es Racó Quartzitic Sandstone Member is early Pliensbachian in age and associated with sea level fall and progrodation of local deltas with the following transgressive facies within a platform environment (Álvaro et al., 1989). Lying above is the Es Cosconar Formation which consists of marls and crinoidal limestones, capped by a ferruginous hardground. The ferruginous hardground is characterised by winnowed iron-rich ammonite debris (Goy et al., 1995).

In the Cutri Area the condensed bed contains ammonite fauna from the Late Toarcian-Aalenian. Overlying this hardground there are nodular and well bedded platy, bioturbated limestones of the Gorg Blau Formation with fauna of the early to middle Aalenian and the Bajocian (Discites to Humphriesianum zones), the Concavum Zone of the late Aalenian was not found (Álvaro et al., 1989). In the Cutri area the marls and marly limestones found in other sections of Mallorca at the lower-intermediate part of the Gorg Blau Formation (late Toarcian-Early Aalenian), here are absent (Álvaro et al., 1989; Goy et al., 1995). The top of the Gorg Blau formation is, in effect an unconformity (Humphriesianum Zone) with evidence of remobilisation, bioturbation and ferruginisation.

Consisting of well bedded mudstones and bioclast rich beds the Cúber Formation is dated to the Bajocian. The Puig d'en Paré Formation contains at its base, highly bioturbated nodular limestones that contain reelaborated ammonites from the late Bajocian (Parkinsoni Zone) to the early Bathonian.

The Puig d'en Paré Formation contains at its base, highly bioturbated nodule limestones that contain reelaborated ammonites from the late Bajocian (Parkinsoni Zone) to the early Bathonian. The upper part of the Puig d'en Paré Formation lies in the Cutri area as filament rich limestones dated to the 
middle Bathonian (Álvaro et al., 1989). Overlying is the $\mathrm{Cu}-$ tri Formation which is therefore likely dated to the late Bathonian- early Callovian (Álvaro et al., 1989). No ammonite fauna unit has been found in the formation so far.

Capping the whole succession are radiolarian-rich mudstones of the Puig de Ses Fites Formation.

\section{Sedimentology of the Cutri Formation}

The area has been divided north and south of the valley created by a strike-slip fault between Puig Cutri and Puig Poloni. The southern sections are defined by their outcrop geometry (Fig. 1c); the 'Puig Cutri Area' is dominated by a massive limestone cliff that cuts into underlying strata and is capped by limestone-mudstone packages. The "Abbots (1989) Southern Section' consists of a series of laterally extensive massive limestone and mudstones; these series of limestones and mudstones has been coined 'The Cutri Formation mega-sequence'.

Areas to the north are divided into two areas named after the topographic peak Puig Poloni. The 'Puig Poloni' area has a very similar geological appearance compared to the 'Abbots (1989) Southern Section' whilst 'Puig Poloni East' has a composition dominated by thick limestone conglomerates.

Based on $127 \mathrm{~m}$ of detailed outcrop studies at 4 locations and 52 polished thin sections and polished rock slabs seven lithofacies have been identified to occur within the Cutri Formation.

\subsection{Puig Cutri Area (C001)}

The Puig Cutri Area immediately surrounds Puig Cutri, and is dominated by a sub-vertical cliff of massive oolitic packstones and grainstones that are up to $30 \mathrm{~m}$ thick (Fig. 4). This cliff is constructed mainly by a large erosional unit consisting of massive oolitic pack-grainstones. It is $\sim 30 \mathrm{~m}$ wide and $\sim 20 \mathrm{~m}$ high with no large boulders or blocks being observed and has geometry indicative of a channel (Álvaro et al., 1984; Abbots, 1989). The channel is orientated $\mathrm{E}-\mathrm{W}$ and cuts downwards in a westerly direction, suggesting an eastward source direction. Additionally large ripples and cross stratification within underlying and overlying wackepackstone rocks are always orientated perpendicular to the overlying orientation.

Similar U-shaped back-filled channels cutting across similar lithofacies have been described by Mullins et al. (1984), Phelps and Kerans, (2007), Noda and Toshimitsu (2009), and Sami et al. (2010). Gully fills that cut into slope mudstone and are similarly plugged with coarser sediment are described from the Oligo-Miocene Numidian Flysch, Tunisia (Sami et al., 2010), the Devonian Prongs Creek Formation, Yukon (Mullins and Cook, 1986),

This cliff is underlain and overlain by pack-grainstone packages and these packages are interbedded with wackepackstones. The pack-grainstone packages are observed to erode into underlying units (see 500, 600 and $1200 \mathrm{~cm}$ on
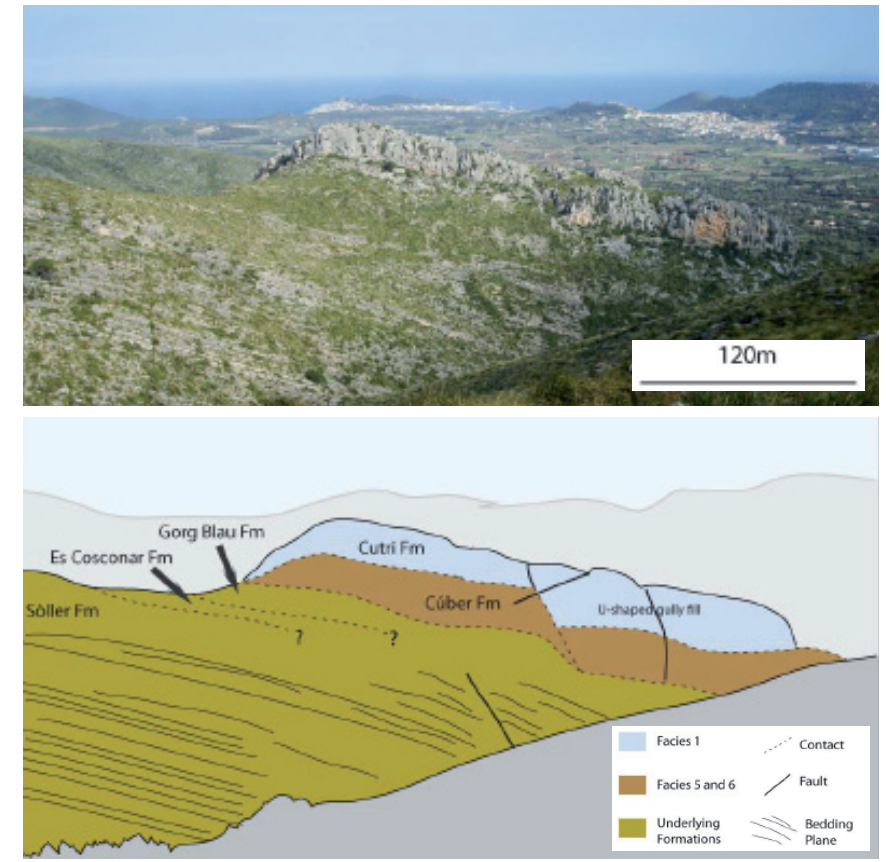

Fig. 4.- Photograph and field sketch of Abbots (1989) Puig Cutri Area. Facing ESE.

Fig. AP1 in the appendix) and incorporate clasts consisting of a wacke-packstones texture.

\subsection{Puig Cutri 'Abbots (1989) Southern Section'(C002)}

The 'Abbots (1989) Southern Section' displays a complete succession through the Cutri Formation (Fig. 5). Normal faults serve to downthrow the section progressively to the south where a more complete stratigraphy is displayed. Each limestone unit has been given a letter from A to Q (A being the oldest Q being the youngest) by Abbots (1989); Fig. 5 . Major limestone units are identified as A, E, H and I; thinner units make up the remaining intervals (the facies relationships and general relationships can be viewed in Fig. 6). The units thin up section eventually giving way to dark fissile mudstone pelagic facies (see composite log C002; Fig. AP2 in appendix) of the Puig de Ses Fites Formation.

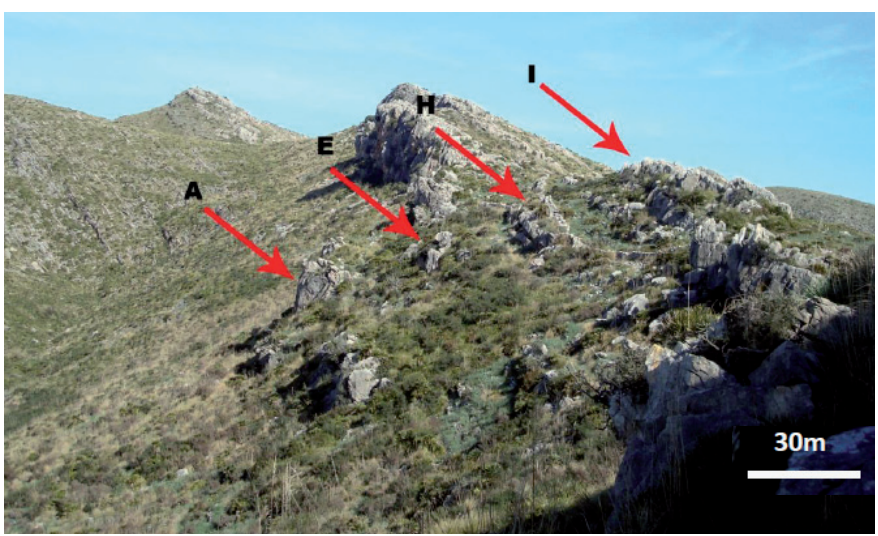

Fig. 5.- Photograph of major turbidite units found in 'Abbots (1989) Southern Section'. Facing NE. 

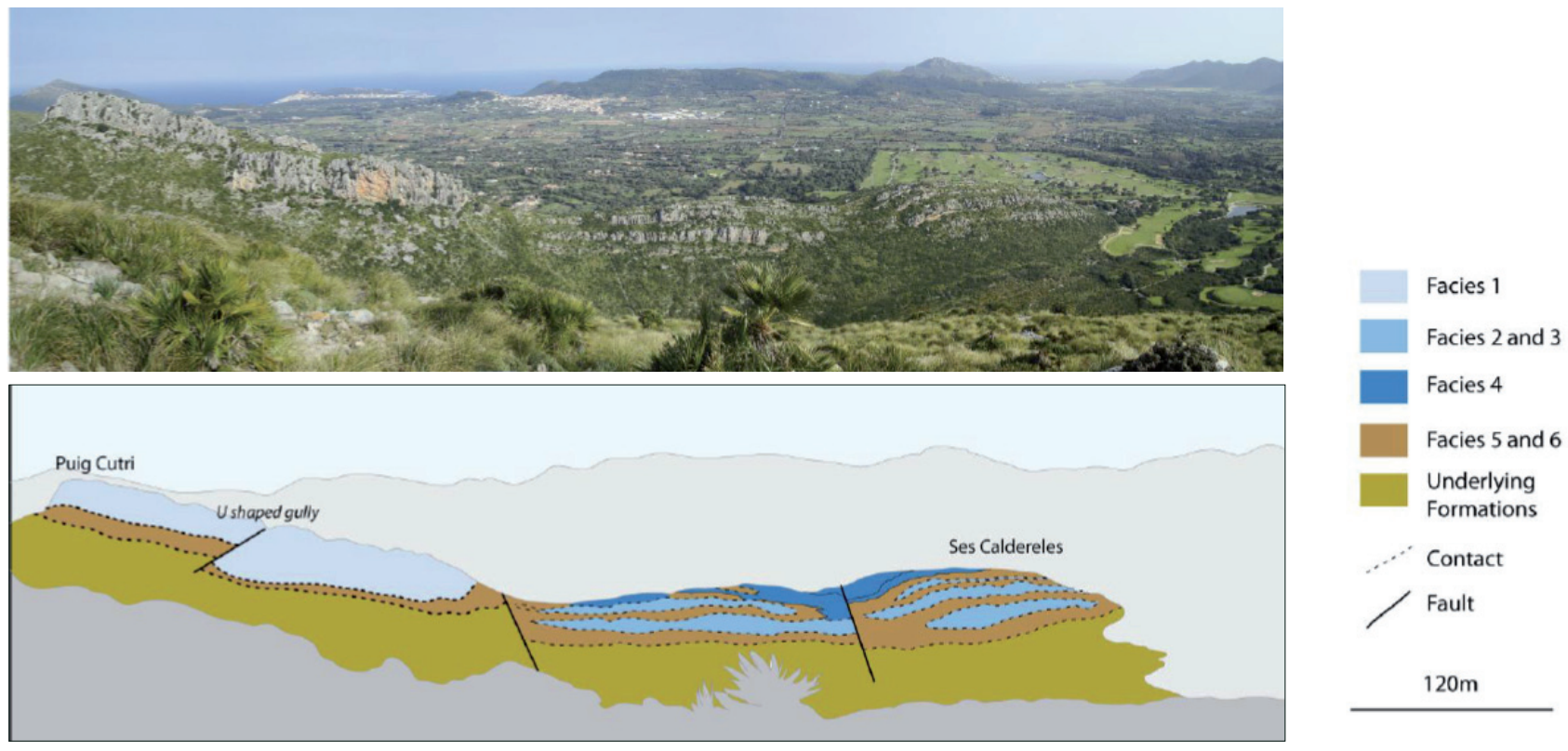

Fig. 6.- Photograph and field sketch of ‘Abbots (1989) Southern Section'. Facing ESE.

\subsection{Puig Poloni (C003)}

At this location the Cutri Formation forms a series of wellexposed near vertical cliffs that form the exposed Puig Poloni ridge. These outcrops present a similar sequence to that of the southern section with the addition of a Posidonia accumulation (Fig. 7) and a thick conglomerate (2050-2150 cm Fig. AP3 in the appendix).

\subsection{Puig Poloni East (C003s)}

Found to the south east of Puig Poloni, being thrust towards the NW, this outcrop has a unique composition compared to other areas as it gives a stratigraphic representation towards the east (Abbots, 1989).

This outcrop has a similar sequence to the southern section. However it has an overall coarser composition (Fig. 8) containing much more conglomerates packages in comparison to other areas (Fig. AP4 of the appendix).

\subsection{Lithofacies description}

The studied succession consists of 7 lithofacies expanded from Barnolas and Simo (1987) including: boulder-pebble conglomerates, graded pebble conglomerates, graded peloidal-ooid packstones, graded oolites, calcilutites, Posidonia coquina and cherty mudstones.

\section{Facies 1 (Boulder pebble conglomerate)}

Description: Boulder-pebble conglomerates occur in the Cutri Formation as parts of thicker graded bed sequences, and individually as distinctive channel fills. This facies is the coarsest facies type in the Cutri Formation and predominantly occurs within the major oolitic channel at Puig Cutri (Fig. $9 \mathrm{~A} ; 30 \mathrm{~m}$ thick by $240 \mathrm{~m}$ wide) and smaller channels at Puig de Poloni and Puig Poloni East (see Fig. 9B and 9C; 5m thick by $50 \mathrm{~m}$ wide). Pebble to boulder conglomerate calcirudites occur as individual beds that form on top of the Puig Cutri
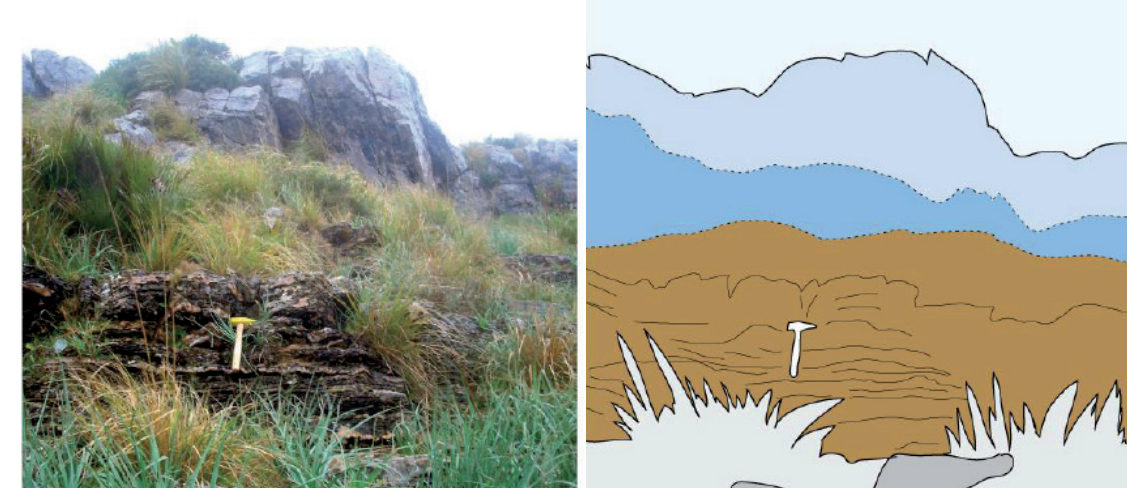

Facies 1

Facies 2 and 3

Facies 6 bank

Fig. 7.- Photograph and field sketch of the Puig Poloni outcrop. Note the dark coquina facies overlain by much lighter coloured turbidite packages. Facing NE. 


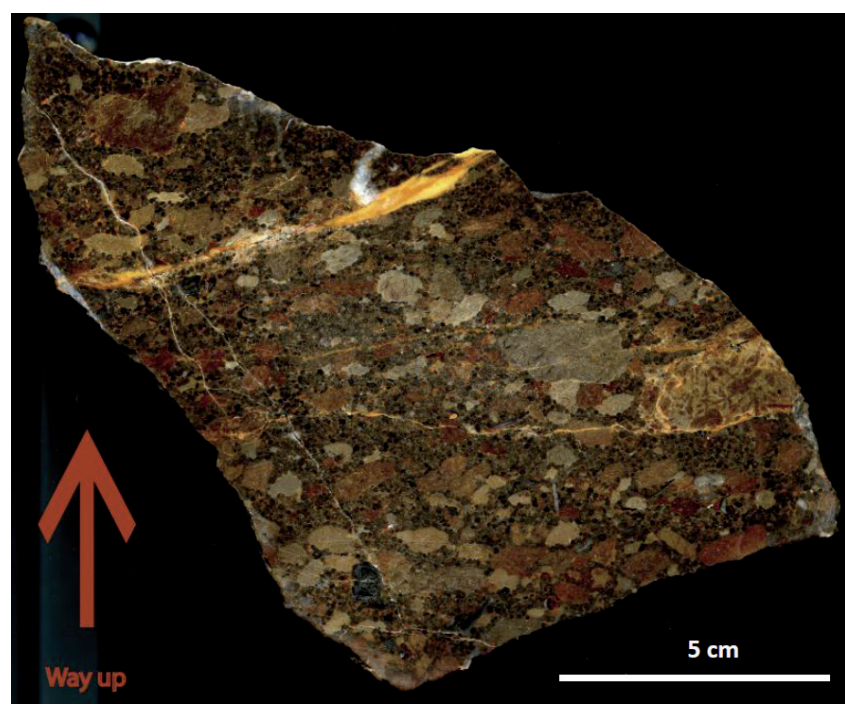

Fig. 8.- Polished slab of facies 1 in Puig Poloni East outcrop. Note the variety of clasts indicating a probable shallower water origin.

and amongst other facies at Puig Poloni. This facies never exceeds $6 \mathrm{~m}$ in thickness.

Sedimentary Structures: The pebble boulder conglomerate facies is a poorly sorted, relatively structureless fine to medium sand grade ooid-peloidal matrix-supported rock. Clasts range from rounded granules to sub-rounded chips, rounded and tabular pebbles and boulder-sized clasts ranging from 10 $\mathrm{cm}$ to $1.75 \mathrm{~m}$ in diameter. Only clasts found within channels show alignment trending to the east, these also have a tabular nature. The boulders appear broken up and frozen in place, and they show no preferential settling or gradation (Fig. 10A).

Microfacies: The matrix is mainly packstone with some local grainstone. The majority of allochems in the matrix are made up of micritised ooids and peloids forming a poorly sorted assemblage of medium to coarse sand grade matrix (Fig. 10B, 10C). Other minor allochems consist of superficial ooids, coated, disarticulated and abraded shell fragments. Boulder to coarse sand sized lithoclasts (Fig. 10C) characterise this facies and are composed of two microfacies types.

Clast type 1 ranges from mudstone to wackestone with a relatively diverse assemblage of micro-ooids, fine echinoderm fragments, sponge spicules and fine abraded shell material. The muddy matrix is dark grey-green in planepolarise light (PPL).

Clast type 2 has an allochem suite that is almost completely dominated by strongly aligned disarticulated and abraded thin shelled bivalves (?Posidonia) and small quantities of fine micropeloids that appear light grey in PPL.

Viewed under cathodoluminescence (CL) the clast types display different cements. Clast type 1 has a dull orange luminescence whilst clast type 2 is brightly luminescent. The matrix of the conglomerate is dull orange with patches of bright orange. The clasts contain cements that are not present in the host matrix.
Deposition Interpretation: The variable clast size (and morphology), poor sorting and matrix-supported nature of this facies suggests these sediments were deposited via a mixture of processes shared by gravity flow deposits (Mulder and Alexander, 2001; Flügel, 2004; Amy et al., 2005; Felix et al., 2009). This facies is interpreted to have been deposited from a debris flow as it is consistently represented by thick beds containing boulders that show no orientation. Other conglomerates containing tabular clasts which are orientated E-W are interpreted to be channel fills that carried coarse sand grade material from the slope edge into the basin. The matrix-supported nature of a debris flow is considered by Amy et al. (2005) to be indicative of a proximal debris flow (e.g. Haughton et al., 2003; Amy and Talling, 2006).

In both channel fill and debris flows the clasts are all observed to have different cement to the matrix which suggests that these clasts were incorporated as semi-lithified slope sediments and probably originated from the shelf edge where marine cements and/or platform top meteoric cements lithified the sediment.

Within both channel fills and debris flows, the coarser clasts would have been supported with the body of the flow by a variety of mechanisms, including the cohesive strength of the matrix and dispersive pressures (Lowe, 1982; Kessler and Moorhouse, 1984; Amy et al, 2005). Since the flows are matrix-supported, the intraclasts were not buoyed within the flow by clast to clast collisions, rather they were probably sustained in flow with finer constituent grain to grain collisions generating dispersive pressures. These dispersive pressures created frictional strength and produced the preferred orientation of tabular clasts to the E-W.

Due to the generally structureless nature of the debris flows they probably did not flow for a long distance and/or have a high water content, allowing for surging or sorting, whilst channel fills contain finer intraclasts that probably travelled into distal environments. Gravity is the main factor that drives these flows, whose velocity and character were a response to the steepness of the slope that the flows ran down. This facies probably originated in the upper slope environment where early lithification allowed intraclasts to be incorporated into flows.

\section{Facies 2 (Graded pebble conglomerate)}

Description: The graded pebble conglomerates occur as well defined beds. Commonly are $<45 \mathrm{~cm}$ in thickness and characteristically contains $>20 \%$ clasts and very coarse peloids.

Sedimentary Structures: The characteristic features of this facies are the dominance of large peloids compared with matrix peloids creating a bimodal sorting, the restriction of clasts to the base of the facies, the occurrence of coarse tail grading and a subtle erosive base (Fig. 11A). The coarse peloids commonly show coarse tail grading that commonly occurs in the basal $5 \mathrm{~cm}$ of the graded pebble conglomerates (Fig. 11B). 
Fig. 9.- Examples of Facies 1 contained in channels. Image A photograph with corresponding field sketch of Puig Cutri looking towards the SW. Image B looking at Puig Poloni and a small channel looking towards NE. C photograph and field sketch of oblique view of a channel, looking towards the SW.
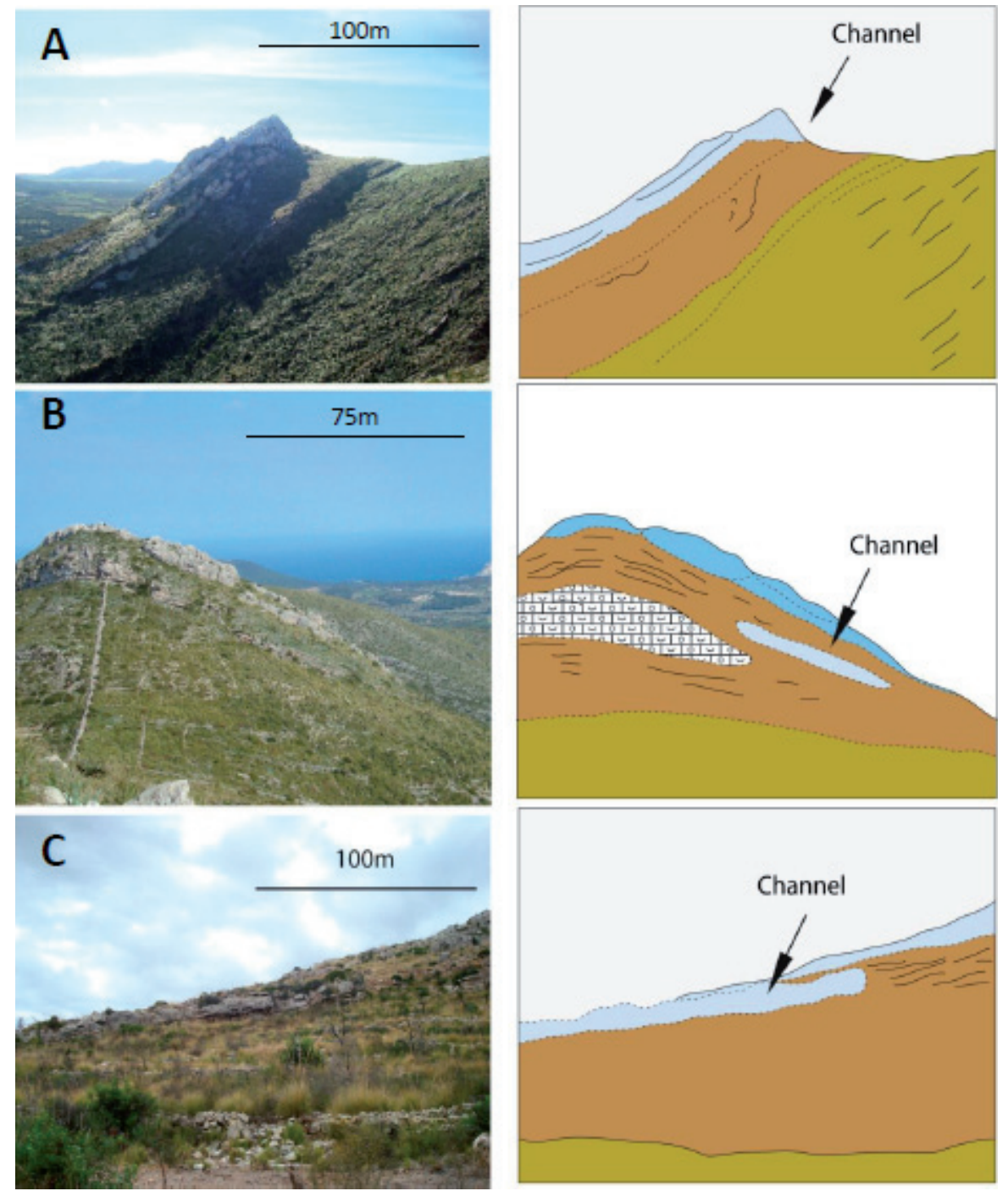

Coarse tail grading of the coarsest peloids dominates the facies, which shows normal grading of ooids and intraclasts whilst the matrix remains massive in nature. The conglomerate is very poorly sorted and the main constituents are medium sand grade allochems that form the matrix, and coarse sand sized to gravel sized peloids and sub-rounded to rounded pebbles, which form the remains of the sediment.

Microfacies: A bimodal, very poorly sorted, packstonegrainstone assemblage of abundant very coarse to pebble sized, subrounded to subangular clasts (same two microfacies as facies 1 clasts) and coarse peloids, which are found within a finer, medium to fine sand grade matrix of deformed radialfibrous ooids, micritic ooids (with a tangential fabric recognisable in peripheral parts) and aggregate grains.

Bioclasts most frequently occur as ooid nuclei which include rare poorly preserved microgastropods, foraminifera, disarticulated and abraded bivalve fragments and other very rare fine sand grade rounded shelly fragments.

Within this facies, ooids have a variety of forms from being completely micritised to showing clear internal structure. Many ooids and other grains have been broken, and show changes in colour from alternating concentric ooid laminae and micritic laminae.

Deposition Interpretation: In a similar fashion to Facies 1 the variable clast size, poor sorting, matrix-supported nature of this facies point to mixture of processes shared by gravity flow deposits. This facies forms the basal divisions of turbidites in the Cutri Formation representing the coarsest section of turbidites, which shows parts of the Bouma ( $\mathrm{Ta}, \mathrm{Tb})$ and Lowe (S1) turbidite sequences.

This clast-dominated horizon conforms to the $\mathrm{S} 1$ division of Lowe's (1982) model for high density and coarse-grained turbidites. It represents deposition by the head of turbidity flows, which were highly erosive and surging in nature (e.g Aalto, 1976) capable of eroding fine-grained muddy slope sediments and integrating them into the body of the flow both as unconsolidated sediment and as semi-lithified slope clasts (e.g. Kano and Takeuchi, 1989; Middleton and Neal, 1989). The clasts within the facies tend to be concentrated towards the base of the flow. The orientation of clasts (WNW-ESE) points to a possible easterly source for the turbidites. 

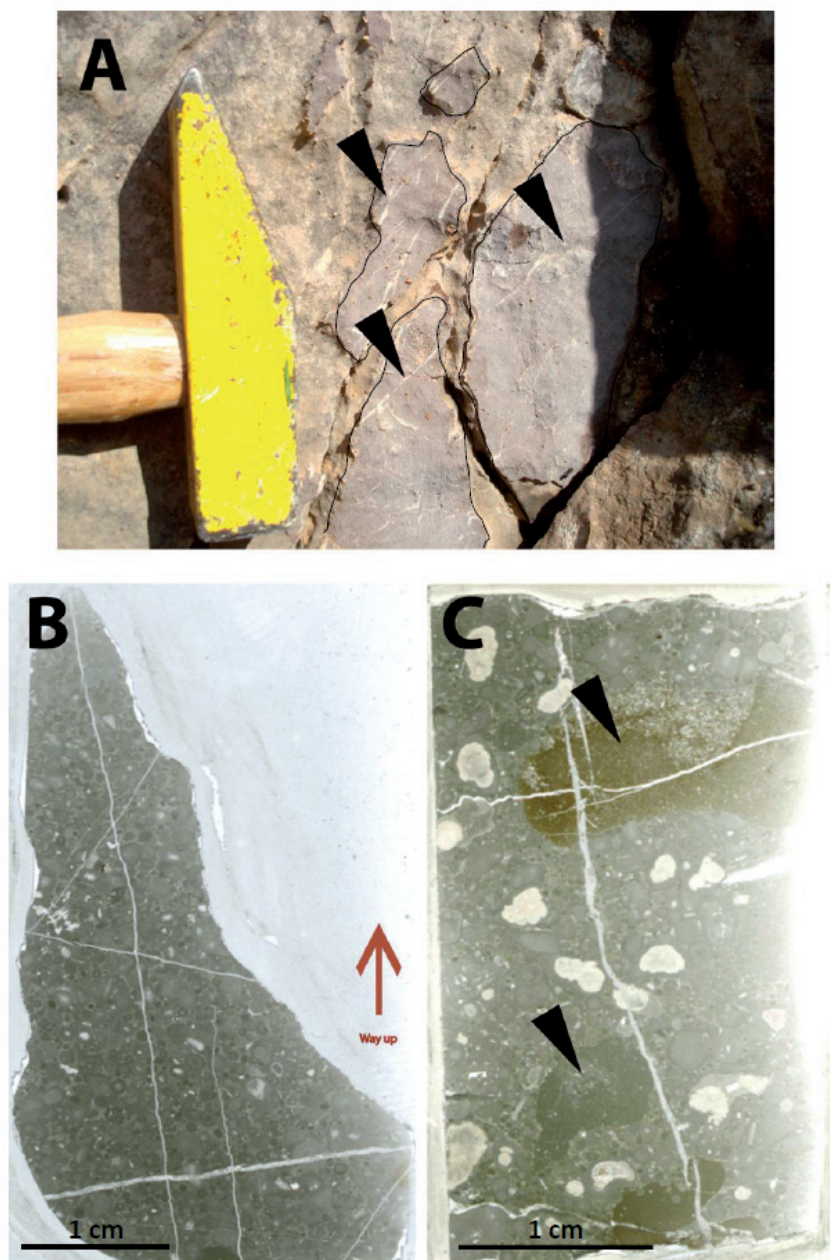

Fig. 10.- An abundance of clasts types and sizes found in facies 1, and appear 'frozen' in flow (A). In image A note the calcite filled fractures in the clasts (outlined in black) that indicate that they were lithified before resedimentation (Hammer head is $15 \mathrm{~cm}$ across; Location C003, $2110 \mathrm{~cm}$ ). (B) Thin section scan of a debris flow note that this is majority matrix (Location C001, $2150 \mathrm{~cm}$ ). (C) Thin section scan of a channel fill, note the abundance of tabular lithoclasts (arrowed) and chert (white clasts) (Location C003).

The basal inverse and coarse tail grading may be due to hydrodynamic phenomena creating a traction carpet. The inverse grading and separation of finer and coarser clasts is typical of the S1 division and is explained via dispersive pressures that stratified clasts creating a much coarser layer (Lowe, 1982).

This facies forms the first division of carbonate turbidites in the Cutri Formation, which is transitional with graded peloidal ooid packstones forming the rest of the Lowe sequence.

\section{Facies 3 (Graded peloidal ooid packstone)}

Description: Facies 3 forms distinctive beds that commonly occur above facies 2 but also occur individually. The beds weather proud and tend to fine up section, ranging from $5 \mathrm{~m}$ to tens of centimetres in thickness.

Sedimentary Structures: The base of facies 3 is commonly represented by a gradational contact with the boulder-pebble conglomerate (Facies 2 ) or a very subtle erosive base. Facies 3 characteristically consists of two principal alternating sedimentary structures as well as an overall grain size decrease up section. The two principal alternating sedimentary structures are concentrated layers of stratified coarse peloids and fine to medium sand grade wackestone clasts which alternate with coarse tail grading found amongst coarse peloids (ranging from $2.5 \mathrm{~mm}$ to $<250 \mu \mathrm{m}$ ).

Microfacies: The facies consists of wacke-packstones to packstones that contain very little bioclastic material with the exception of Posidonia bivalves which occasionally form aligned accumulations near the top of beds just below the finest portions of this facies. Other bioclasts that form constituent parts of the matrix are large benthic foraminifera, abraded echinoderm fragments, microgastropods and other shelly fragments. These bioclasts almost always have a micritic coat and commonly form the nuclei of coated grains.

A general fining up sequence is noted that consists of very coarse to coarse sand grade ooid-peloidal sediment near the base to a massive medium to medium-fine sand grade ooidpeloidal sediment.

Throughout this general graded sequence are alternating microfacies consisting of coarse to medium sand and concentrated beds of stratified oversized peloids of coarse sand grade size capped by fine laminations of coarse tail grading and inverse grading of ooids and peloids.

Deposition Interpretation: Facies 3 is characterised by a general graded nature and a succession of alternating microfacies including grading of peloids, inclusion of mudwackestone clasts and stratification of grains to reflect the deposition of sediments by high-density turbidity flows. The facies displays Lowe's (1982) coarse-grained turbidite classification divisions $\mathrm{S} 2$ and $\mathrm{S} 3$.

$\mathrm{S} 2$ is characterised by the gradational contact with facies 2 and concentration of graded coarse peloids. The base of this facies is related to the $\mathrm{S} 1$ division and the changing hydrodynamic conditions after deposition of the graded pebble conglomerates. Throughout this division are alternating microfacies becoming thinner up section resulting in a gradual reduction in coarse peloids compared to the oolite portions that themselves show little change in grain size. This phenomena is a possible example of surging within the turbidite. The "pulses" of material can be seen in outcrop as thin traction carpets overlain by thicker suspension sediment horizons.

This sequence grades, with eventual loss of pulsing energy, into final deposits of finer grade subtly laminated peloidaloolitic material; this is interpreted as the $\mathrm{S} 3$ division of the turbidite and represents the dwindling of dispersive energy with the increasing dominance of suspension as a depositional mechanism.

The S3 division contains a subtly planar laminated to massive fine- to medium-sand grade sediment with subtle waterescape features (noted by Abbots, 1989) and subtle wavy laminations. The sediments here indicate suspension has overtaken other depositional mechanisms and accumulated rapid- 

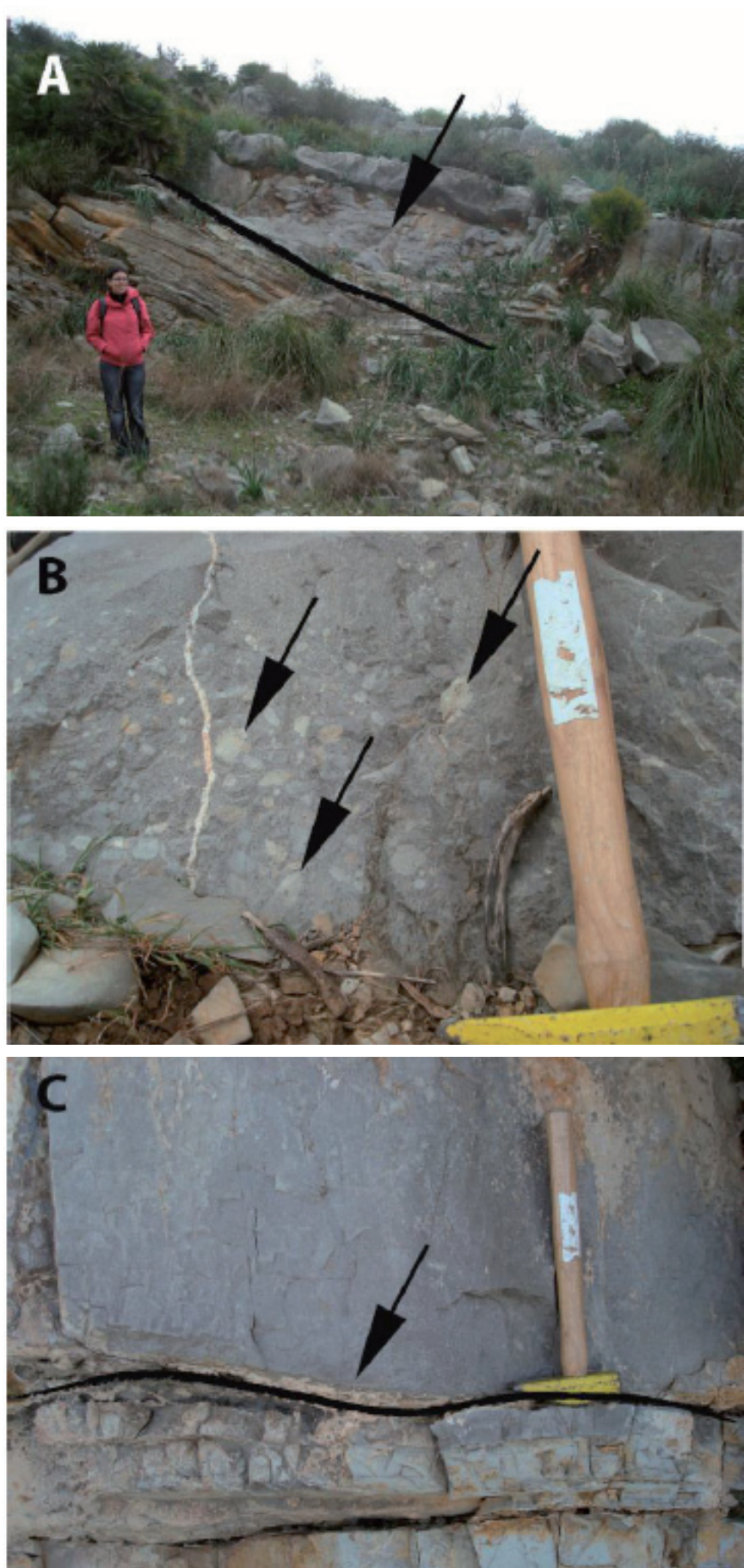

Fig. 11.- A) Outcrop image of Facies 2 in comparison to background sedimentation at location C002. B) Graded pebble conglomerate; note the hammer is $30 \mathrm{~cm}$ in length (C002 approx $475-510 \mathrm{~cm}) . \mathrm{C}$ ) Detail of erosive basal contact between Facies 2 and finer background sediments (C001 approx. $600 \mathrm{~cm})$.

ly as the growing surface of the bed coincided with the suspended cloud leading to very rapid deposition, as suggested by water-escape features. The remaining $\mathrm{S} 3$ division consists of a fining up sequence to a mudstone that caps the turbidite.

The sequence of events and processes above is indicative for the sequence first described by Lowe (1982) which indicates the sediments of the Cutri Formation were deposited through high density turbidites.

\section{Facies 4 (Graded oolites)}

Description: This calcarenite has a fine to medium sand grade oolitic-peloidal matrix occurring as thin beds (always $<1 \mathrm{~m})$. The beds are commonly less than half a metre thick with both tops and bases being planar. Normal grading occurs from a basal medium to coarse sand fining up to fine sand to silt-grade sediment. This sequence is capped by a laminated mud.

Sedimentary Structures: Normal grading of the coarsest material (medium to fine-sand grade allochems) and subtle dispersive grading of the coarse material has blurred the clarity of normal grading.

Microfacies: This calcarenite is commonly a wackestonepackstone and is characterised by subtle normal grading of sparse fine sand to medium sand grade peloids and ooids found within a micrite matrix, which often consists of 50$70 \%$ of the rock. Allochems are laminated subparallel to bedding with the most widespread bioclasts being fine to medium sand-grade disarticulated and abraded thin shelled bivalves (?Posidonia), fine echinoderm debris, rare biserial foraminifera, and other shelly debris. In CL these microfacies have always a dull brown-orange luminescence.

Deposition Interpretation: This facies represents distal turbidites that consist of much finer material than facies 3 and distribution grading, which indicates deposition by minimal turbulence and dispersive pressures between grains (Lowe, 1982). This facies is characterised by the upper part of the Bouma graded bed sequence and some features of the Lowe $\mathrm{S} 3$ division. The bioclast assemblage is very similar to facies 3 suggesting that these facies may have a similar source.

\section{Facies 5 (Calcilutites)}

Description: Muddy beds intervene between the coarser facies of facies 1,2, 3 and 4 and consist of very fine sand to silt to mudstones, wackestones and fissile- often cherty mudstones. They appear in outcrop as accumulations of weathered grey, brown and orangey-brown lithologies. The units range from $1 \mathrm{~m}$ to $2.5 \mathrm{~m}$ thick and are made up of $2-5 \mathrm{~cm}$ thick beds and laminations of light brown-yellow and grey muds. Beds consist of fine wavy laminations (1-10 mm; Fig. 11) and have common inverse grading, particularly within the coarsest sediments.

Sedimentary Structures: Normal grading (Fig. 11), lenticular and wavy laminations, cross bedding, ripple-like features and abundant bioturbation also characterise this facies. The largest sedimentary structures are large wavy structure with a 1 to 2 metre wavelength and 10-30 $\mathrm{cm}$ amplitude (Fig. 11). Within these large structures are another set of smaller wavy laminations that are between 20 and $30 \mathrm{~cm}$ in wavelength occurring subtly within individual beds.

Bioturbation is abundant in this facies typically consisting of distinct Chondrites and Planolites type burrows as well as rarer Zoophycos. Other larger bioturbation structures are 

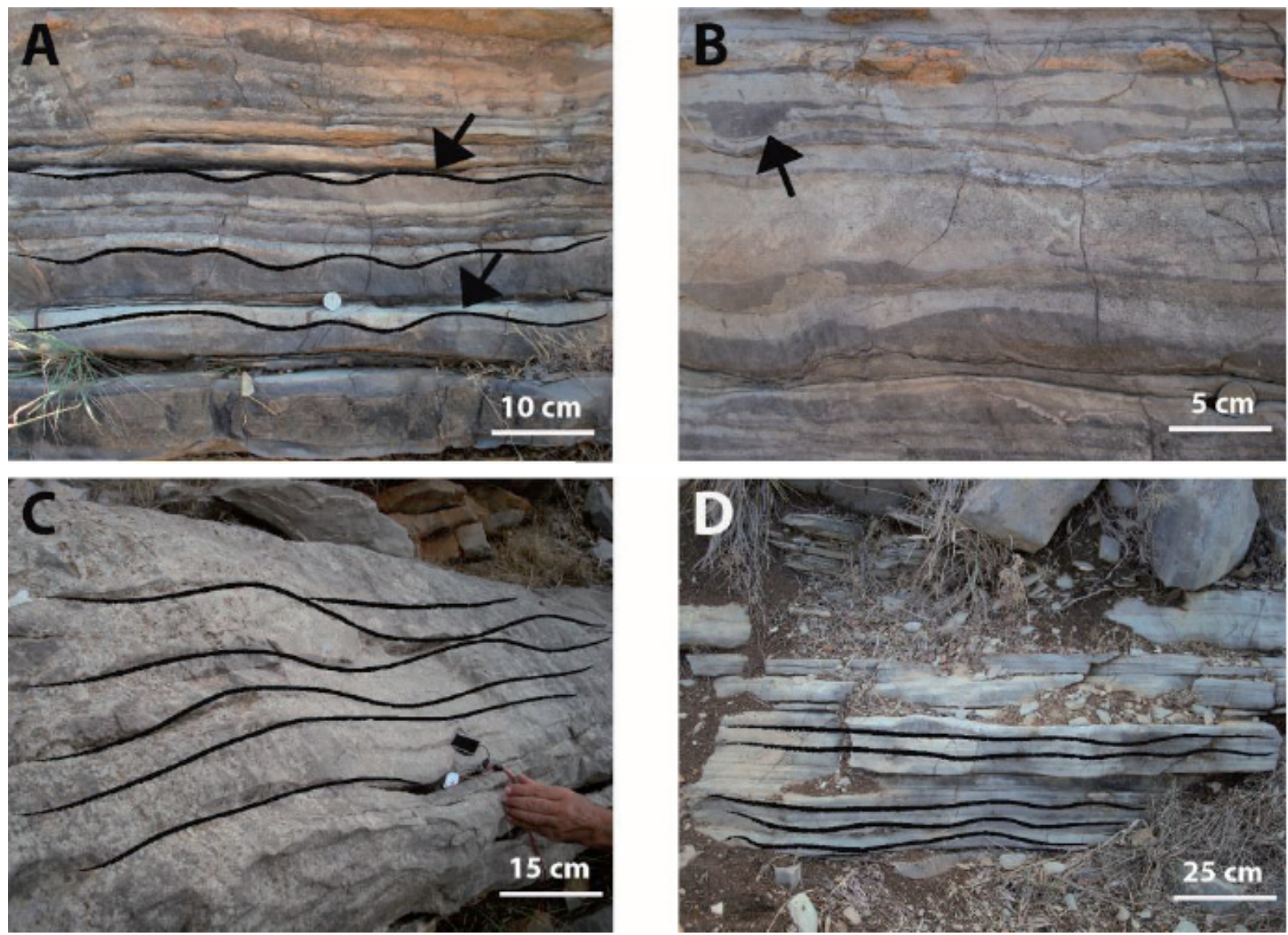

Fig. 12.- Sedimentary structures of facies 5. All Figures consist of part of a succession of "wavy" structures (1-2m wavelength) that dampen up section where planar laminations prevail (note D). Top left arrow in image B indicates a burrow that truncates underlying laminations.

noted that truncate laminations (Fig. 11). Amongst the wavy laminations chert nodules are common, found following the bedding planes.

Microfacies: A variety of microfacies are found within the calcilutites of the Cutri Formation. These vary from mudstones to well-orientated Posidonia dominated wackestones to strongly graded calcisiltite that contain rare silt grade peloids, rare poorly preserved foraminifera and other shelly fragments. The majority of the laminations consist of 50$70 \%$ micritic matrix with occasional accumulations of Posidonia bivalves that make up $>50 \%$ of the bed (Fig. 12). All microfacies are commonly disrupted by bioturbation. Fossil types are most commonly Posidonia thin shelled bivalves with rare occurrences of single foraminiferas and other thin shelled bivalve species.

Deposition Interpretation: Normal grading, ripples-like structures, cross stratification and laminations distinguish this facies as a current influenced accumulation. The entire facies hosts a general fining-up sequence with individual beds showing fining-up in grain size, suggesting a decreasing influx of coarser sediment that may have been deposited via an accumulation of dilute turbidity flows and suspended fines resulting from the deposition of turbidity flows and background deposition.

The facies is distinguished by its large ripples-like structures that contain laminations that have preserved cross stratification and smaller ripples within the much larger ripples-like structures; this deposit is considered a possible representative of C4 in Stow et al. (2002) classification. Overlying these silty deposits are massive and fissile structureless mudstones that are interpreted as originating as pelagic mud deposits (Abbots, 1989) and as C1/C6 of Stow et al. (2002) classification. The peloidal wackestones and packstones are interpreted as C5 of Stow et al. (2002) classification.

\section{Facies 6 (Coquina)}

Description: Notable accumulations of bivalves occur within this facies and are found only within calcilutites forming flat bottom lens-shaped banks with dimensions of $\sim 30 \mathrm{~m}$ wide by $\sim 10 \mathrm{~m}$ height. These accumulations are commonly interbedded with thin beds of massive carbonate mud forming in association with facies 5 . These accumulations are moderately well-sorted and occasionally show a rhythmic gradation with mud-rich laminations becoming more frequent up section.

Sedimentary Structures: Pseudo-laminations characterise this facies; however, this is caused by the alignment of bivalves within the rock.

Microfacies: Strongly-orientated parallel to bedding Posidonia or ?Bositra bivalves, coarse unidentifiable shelly debris and abraded echinoderm fragments that are lined with 

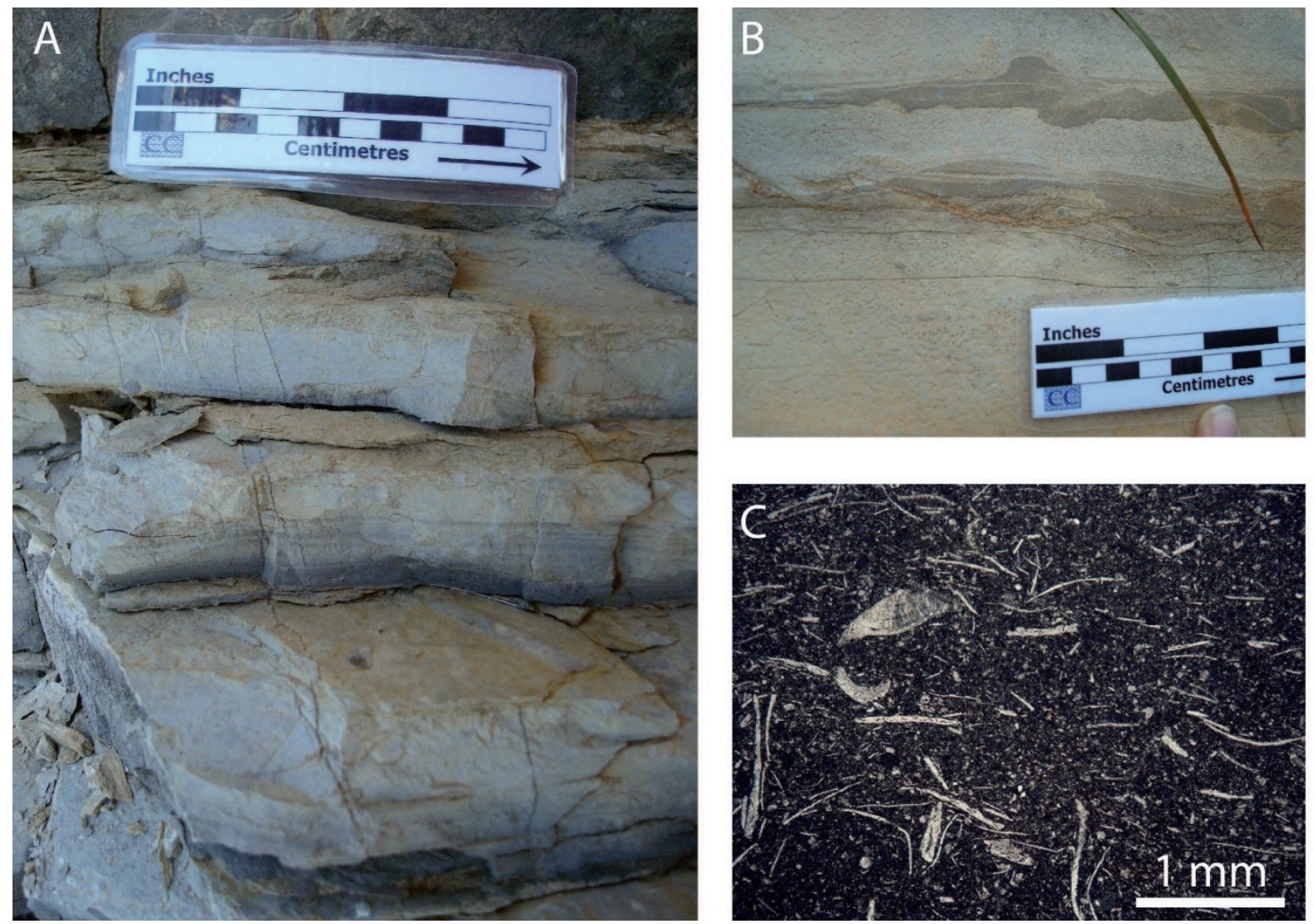

Fig. 13.- A) and B) Outcrop image of facies 5 note the very clear graded sequences in A and bioturbation, wispy laminations and cross bedding in B. C) Photomicrograph of facies 5 note the change in orientation of allochems in off centre position; this is due to bioturbation.

dark brown to black mud forming laminations dominate this microfacies (Fig. 13). Note that the packstone nature seen in Figure 13 is likely a product of compaction. The Posidonia bivalve fragments are up to $1 \mathrm{~cm}$ in length and very thin, averaging about $0.05 \mathrm{~mm}$, and have a uniform thickness along their length (Fig. 14). The majority of bivalves are broken and disarticulated, with boring being rare. However, bioturbation is common and disturbs the laminations most often being Chondrites and Planolites type burrows. Compaction has been intense and made it difficult to judge how the bivalves were orientated during deposition. The bivalves show an orientation which is parallel to sub parallel to bedding.

Deposition Interpretation: Posidonia bivalves are characteristic of deeper water environments (Navarro et al., 2009). In the Cutri Formation they have been observed to occur alongside other faunal remains characteristic of deep water environments such as radiolaria (Abbots, 1989) and planktonic fauna. The constituent grains are commonly aligned parallel to the bedding, this orientation was likely to have been enhanced through compaction. These coquina accumu-
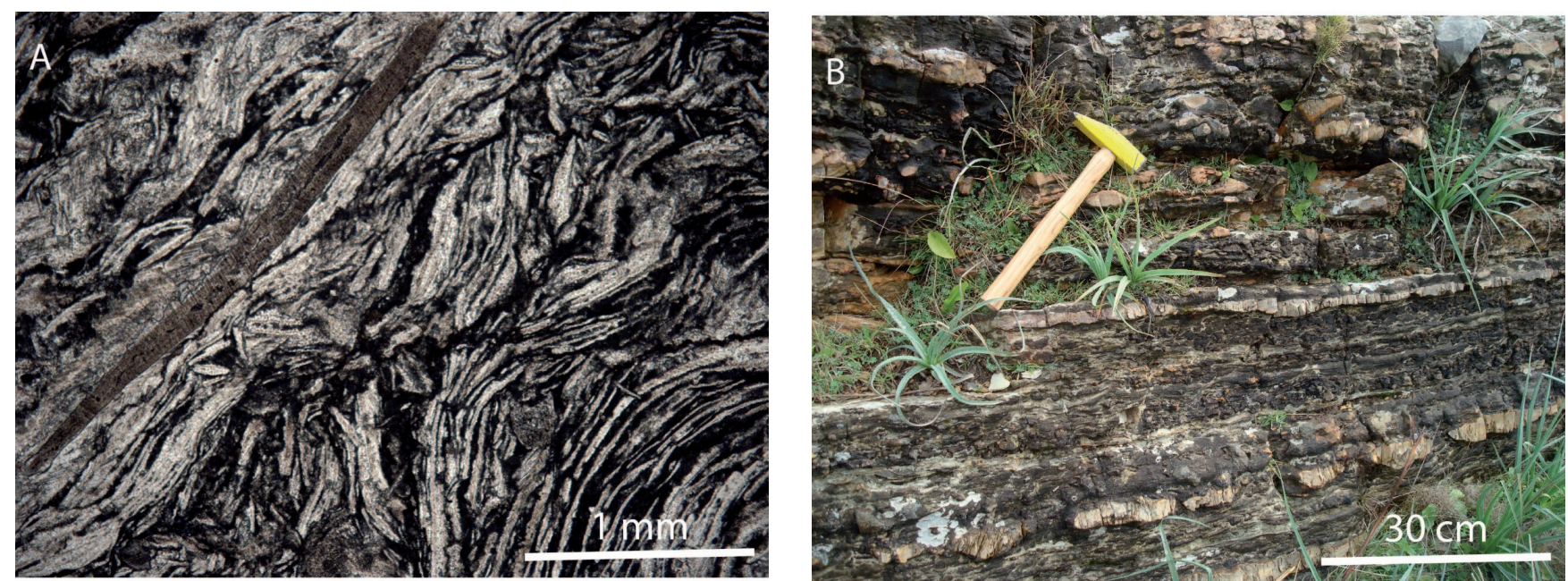

Fig. 14.- Photomicrograph and outcrop photograph of facies 6. 

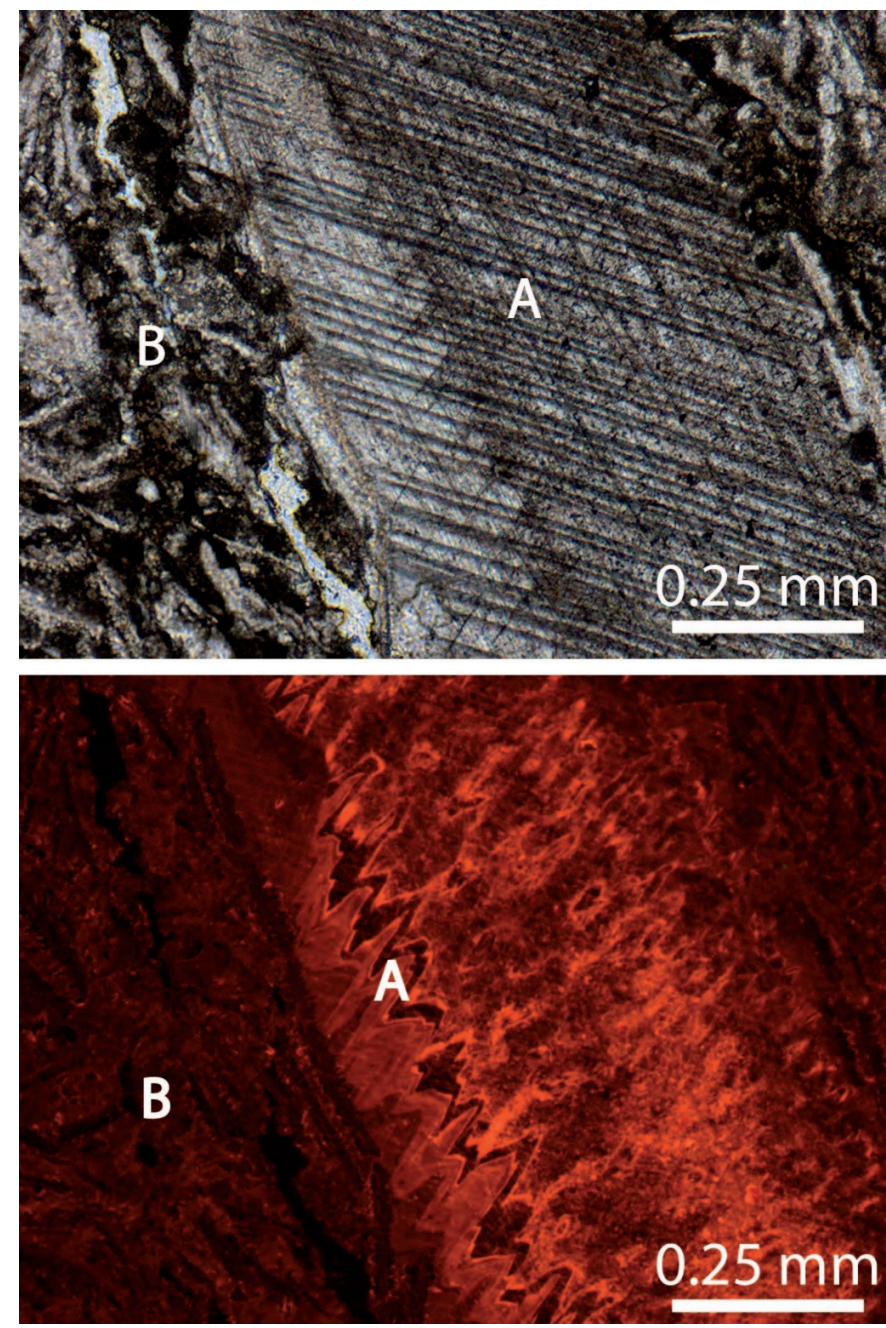

Fig. 15.- Photomicrograph and cathodoluminescence view of a Bositra bivalve amongst fine bivalve debris. A indicates the internal structure of a shell. B indicates matrix composition.

lations locally alternate with thin layers of pelagic mud (Fig. 14). This pelagic mud, found compacted between individual bivalves, gives the coquinas a black colour in outcrop. Burrowing occasionally disturb the fine laminations, the low diversity of ichnotraces suggesting a restricted environment within the area of deposition (Seilacher, 2007).

Complete specimens of the bivalves were not found in the outcrop, only disarticulated bivalves were seen. Posidonia are the most commonly reported in the Subbetic (e.g. Colom 1975, Linares and Vera, 1966; Azéma et al., 1971, Gonzalez-Donoso et al., 1971, Rivas 1975, Rivas et al., 1997) suggesting that the bivalve was widespread across that part of the Tethys Ocean.

Rivas (1975) described the distinctive features of Bositra compared with Entolium. Unfortunately, fossil characteristics were insufficient to identify the bivalves as either Bositra or Entolium genera. However, Bositra is commonly found within resedimented facies in this setting during the Jurassic (e.g. Portugal (Wright and Wilson, 1984); Subbetic Cordillera (Mamet and Préat, 2006); France (Olivero and Gaillard, 1996); Southern Alps, Italy (Cobianchi and Picotti, 2001).

\section{Facies 7 (Mudstones)}

Description: Mudstones occur locally up to $2 \mathrm{~m}$ thick (Fig. 15 ), but more commonly are $\mathrm{cm}$ thick. This facies is mainly observed overlying the Cutri Formation, most notably at Puig Cutri. It is also found interbedded between the occurrences of facies 2 and 3.

Sedimentary Structures: Chert nodules dominate the facies and follow bedding planes commonly up to $10 \mathrm{~cm}$ in length. Subtle laminations are noted in a few locations that run parallel to bedding often hosting chert nodules. This facies always has a planar contact with the underlying sediments.

Microfacies: Varying from well-orientated carbonate mudwackestone that consists mainly of well-rounded poorly-preserved silt-sized calcite grains (probably disarticulated and eroded bivalve fragments) and radiolaria to complete micritedominated accumulations. The microfacies often exhibit burrows and an abundance of chalcedony grains. Bioturbation is common and consists of Planolites burrows and other general mixing of the sediment.

Deposition Interpretation: The presence of radiolarians in this facies and the inclusion of fine grained poorly preserved calcite material, similar to those found in facies 5 suggest that this facies may represent very fine sediments being transported into the deep basin by suspension. These were likely deposited alongside pelagic and periplatform sediments rather than representing true pelagic deposition which characterise the overlying Puig de Ses Fites Formation.

\section{Discussion}

The Cutri Formation is interpreted as a grain-rich gravity flow complex, where debrites are found in the stratigraphically youngest as well as most proximal sections and tur-

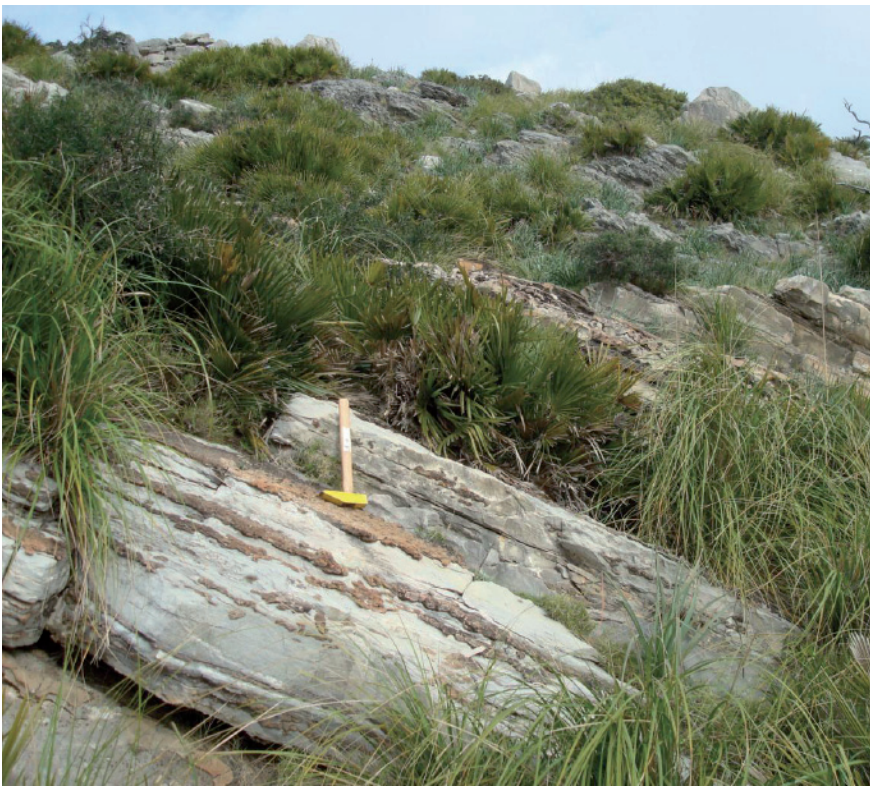

Fig. 16.- Outcrop of facies 7. Note the abundance of chert nodules that follow bedding planes. Hammer $30 \mathrm{~cm}$ in length. 


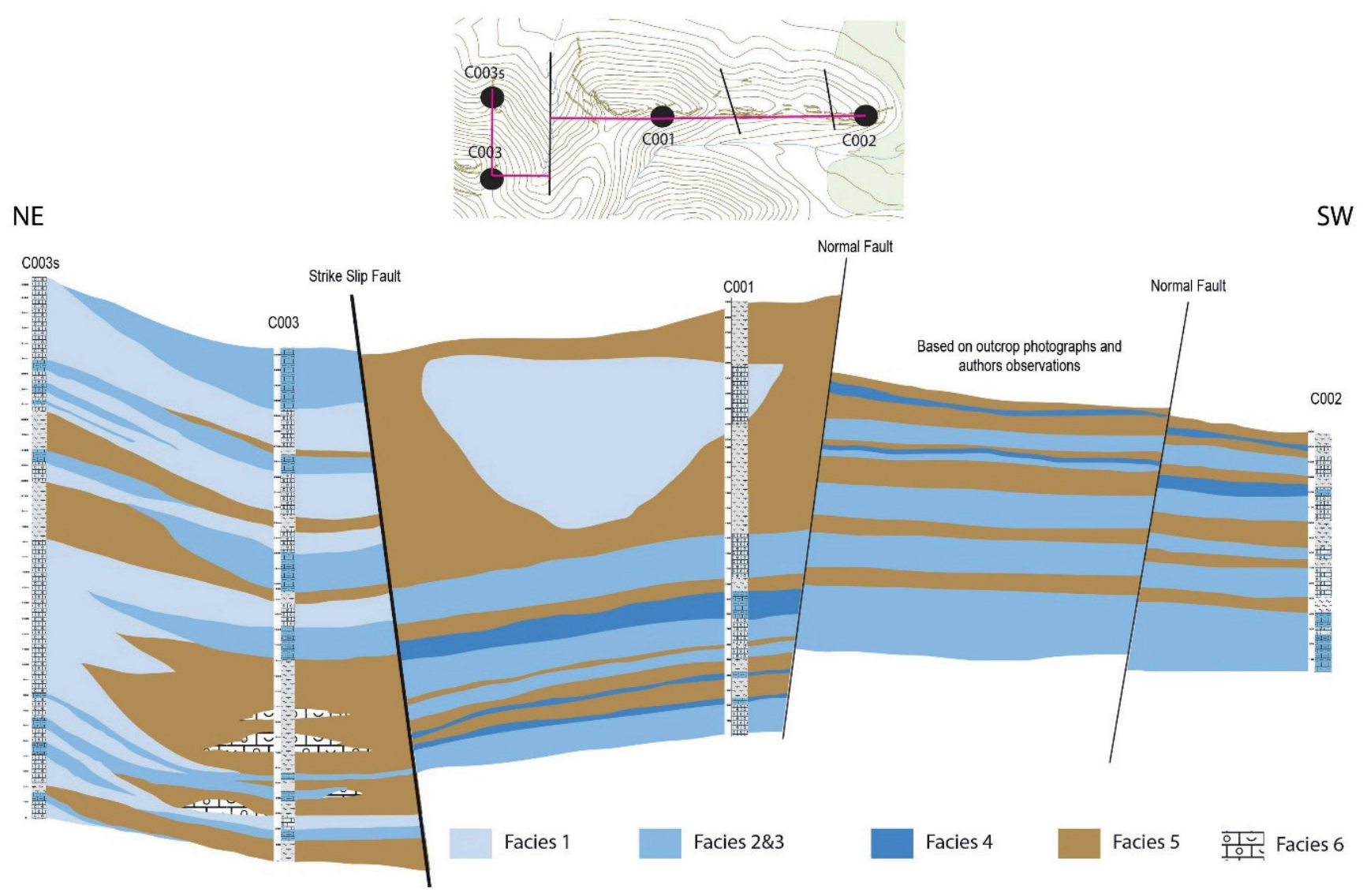

Fig. 17.- Fence diagram summarizing the $2 \mathrm{D}$ associations between facies

bidites are found throughout the formation that thin up-section. The complex is dominated by silty bioclastic mudstones and wackestones that interbed those debrites and turbidites. The overall domination of muds and fine-grained sediments suggests that this sedimentary body was probably formed on a windward margin where sands from the slope top were being deposited on-bank. This is a characteristic feature of windward margins where transport of resedimented grains and finer muds and silts dominate the slope and base-of-slope environment. Ancient examples of windward margins include the eastern side of the Valles-San Luis Potosi; Minero, (1991), Tuxpan Platforms; Enos and Stephen, (1991), Los Molles Formation, Chile (e.g. Bell and Suárez, 1995), Poza Rica field (e.g. Janson et al., 2011) and Wolfcampian/Leonard carbonates in the Midland Basin, U.S.A (e.g. Dutton et al., 2004).

The allochems found within grain dominated elements (i.e. facies 1, 2 and 3) suggest an origin in shallow water where the development of ooids and aggregate grains took place in high energy settings and peloids and micritised grains lowerenergy settings. The high energy environment of the sediment source is further indicated by the inclusion of semi-lithified intraclasts that are abundant in more proximal deposits. Their inclusion indicates that erosion due to both wave energy and gravity flows were eroding the slope. Other locations (C001, $\mathrm{C} 002$ and $\mathrm{C003}$ ) represent those deposits further downslope where a finer, although coarse grade sediment, is preserved.
It is discussed in Abbots (1989) that upper slope deposits occur on the island of Cabrera, geologically part of the Sierra de Levante but separated from Mallorca to the SSW. Abbots (1989) reinterpreted what was described as a "conjugate olistolith" by Arbona et al. (1984-1985) as being an upper slope gully fill, plugged with oolitic limestones and is recognised as being equivalent to the Cutri Formation. This succession is interpreted to be the upper slope environment of the platform. Furthermore, Abbots' (1989) upper slope deposits are described as consisting of "thin-bedded oolitic grainstones and wackestones with Posidonia ...overlain by... [erosive]... carbonate conglomerates" forming gully fills and as having a wackestone packstone microfacies rich in filaments of Bositra. This succession of oolitic grainstones and wackestones characterises the studied strata. Additionally, Posidonia rich wackestones are observed in this study as forming lithoclasts within facies 1 and 2 suggesting that the clasts are possibly the preserved upper slope/source area of the Cutri Formation deposits suggesting that the clasts are possibly the only representative of the upper slope source area of the Cutri Formation deposits. It is assumed, due to the high proportion of ooids within the turbidites that the source of the Cutri Formation was probably from high-energy environments or from spill-over of such environments.

The predominance of ripple-like features, fining-up sequences, strong alignment of allochems, and parallel-laminated beds within facies 5 indicates a gentle reworking by 
bottom currents and deposition of a muddy to sandy contourite. Material for these possible-contourites were sourced from a mixture of suspended sediments, dilute turbidites and probable storm events that incorporated platform grains into the system. Posidonia bivalves form a bank in one location and are commonly found amongst facies 5 .

Facies 7 was first interpreted by Abbots (1989) to represent the Puig de Ses Fites Formation that overlies the Cutri Formation partly based on the occurrence of radiolarians that reflect the continuous widening of the Neotethys Ocean. The boundary between these two formations is represented by a hiatus during the Bathonian-Oxfordian. However, the inability to correlate the boundary between the Cutri and Puig de Ses Fites Formation by contact types or biostratigraphy (due to the resedimented nature of these sediments) leaves open to interpretation the timing of deposition and whether this facies was associated with the resedimented facies of the Cutri Formation or the true pelagic sediments of the Puig de Ses Fites Formation.

Figure 16 illustrates the sedimentary geometries and relationships between the above discussed facies. Note the relatively extensive linear accumulation of turbidites between $\mathrm{C} 001$ and C002, this is the Cutri Megasequence. Within these outcrops the strike-slip fault noted to occur between $\mathrm{C} 001$ and $\mathrm{C} 003$ and $\mathrm{C} 003 \mathrm{~s}$ enables a view of more proximal deposits.

\subsection{Deposition Model}

The slope characteristics and proximity to the slope break probably have the greatest influence on what type of depos- its occur at the base-of-slope and further beyond at the toeof-slope and basin floor. The Cutri Formation debrites and turbidites contain two types of lithoclasts suggesting that these deposits were formed on a heterogeneous carbonate slope dominated by the Posidonia bivalve, rather than further downslope in the probably more homogeneous mud-rich lower slope and basinal areas.

Moving up the stratigraphic sections the rocks display continuously deepening and increasingly distal sedimentary environments. The mixture of facies within the formation has also being described in other examples (e.g. Mullins and Cook, 1986) and points to the Cutri Formation most likely representing a base-of-slope carbonate apron rather than a fan type deposit (e.g. Wright and Wilson, 1984), with its origin probably created by changing tectonic and palaeogeographical events.

Apron complexes are characterised by the presence of many channels and small gullies that cut the slope (e.g. Mullins and Cook, 1986; Hüneke and Krienke, 2004), and feed sediment into a distinctively linear apron complex that forms parallel to the platform (e.g. the modern Bahamas slope, Mullins et al., 1984 and the Tuxpan Platform, Janson et al., 2011). This apron system is characterised by multiple sources along a margin rather than a single point source. This difference between point and linear source deposits have been described by Mullins and Cook (1986) and Colacicchi and Baldanza (1986).

As previously discussed the Cutri Formation is considered to have formed between $25-30^{\circ} \mathrm{N}$ suggesting that it may have had a subtropical climate where storms are modelled to have been common during the summer (Arias, 2008). Using Arias
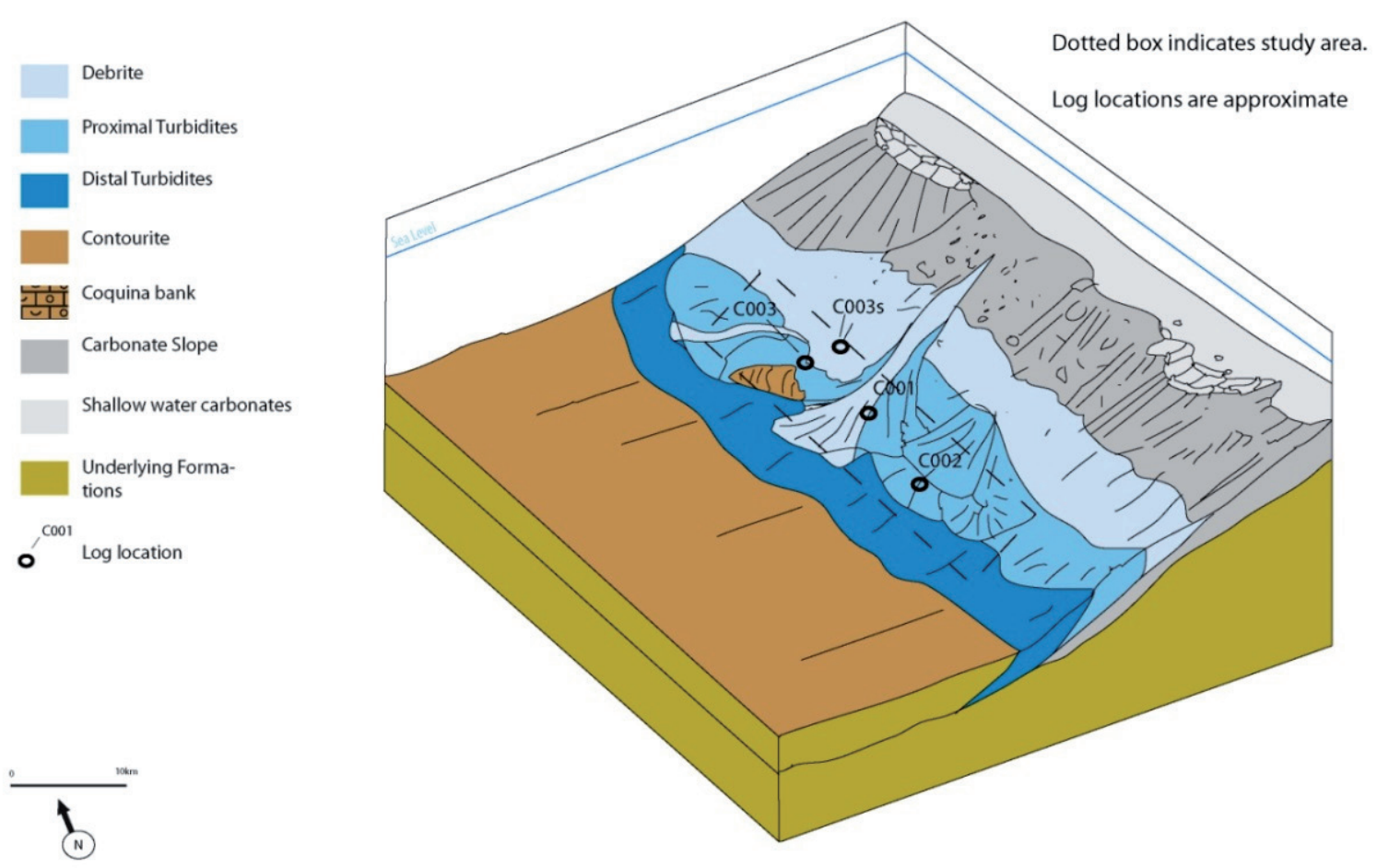

Fig. 18.- Depositional model for final deposition of the Cutri Formation. Note the location of logs which have been incorporated to indicate the spatial distribution of sedimentary geometries illustrated in 2D from Figure 17. 
(2008) climatic models it is possible to suggest that this area would have had a seasonal climate not unlike the subtropical Caribbean Sea where hurricanes are recognized to play an important role in sediment transfer. Eustatic control and storm events, probably resulting in increased instability, encouraged gravity flow sedimentation into current swept platform slope areas.

Tectonics is an additional factor to the eustatic and climate influences that increase the likelihood of resedimentation. The Cutri Formation was deposited during a rifting stage. Evidence discussed from the island of Cabrera by Abbots (1989) suggests that the margin was formed on a footwall and was tectonically active during the time of deposition. The carbonate apron complex has slope sediments that form an extensive; basinwards thinning accumulation of resedimented carbonate sediment (see model in Fig. 18). The retrogradational upward pattern (overall decrease in coarseness and thickness) seen in the Cutri Formation is suggestive of a subsidence regime. This subsidence regime is directly related to the Neotethys Ocean rifts that created unstable platform tops through oversteepening.

\section{Conclusions}

The Cutri Formation is interpreted as a base-of-slope apron deposit characterised by a thinning up-wards sequence indicating increasing distiality from source. The apron is composed of debris-flow deposits and distinct oolitic turbidite units that are laterally extensive, interbedded by mudstones and packstones interpreted to be possible contourite deposits. The turbidites are high-density and are identified to have been sourced from a probable easterly location. Slope deposits are noted to occur further to the south on the Island of Cabrera suggesting that this platform was a significant size.

The apron likely formed during the late-Bathonian, a period of sea level rise which may explain the overall thinningup sequence as the carbonate platform migrated away from its original location as it increased the intensity of carbonate growth towards the rising sea level. However tectonic control is considered to have taken a more direct role in initiating deposition of the Cutri Formation where Abbots (1989) investigation of the Island of Cabrera indicated the presence of a large normal fault to the platform edge.

The overall fine-grained nature of the formation indicates that these deposits were likely formed on the windward margin of a carbonate platform.

\section{Acknowledgements}

Thank you to Cambridge Carbonates Ltd for providing funding and support for this project that came about from the study for an M.Phil thesis at the University of Birmingham. Thank you to Dr Luis Pomar for his observations in the field and Scott Thackrey of Maersk Oil \& Gas for his comments on this article. Finally I am hugely grateful for the comments and feedback by the reviewers of this article and in particular Dr Idoia Rosales of IGME.

\section{References}

Aalto, K. R. (1976): Sedimentology of a mélange: Franciscan of Trinidad, California. Journal of Sedimentary Petrology 46,13-929. doi: 10.1306/212F7090-2B24-11D7-8648000102C1865D

Abbots, F. V. (1989): Sedimentology of Jurassic syn-rift resedimented carbonate sandbodies. PhD Thesis, University of Bristol, 403p.

Álvaro, M., Barnolas, A., Del Olmo, P., Ramírez del Pozo, J., Simó, A. (eds) (1984): Sedimentología del Jurásico de Mallorca. GEM-IGMECGS, 43-71

Álvaro, M., Barnolas, A., Cabra, P., Comas-Rengifo, M. J., FernándezLópez, S. R., Goy, A., Del Olmo, P., Ramírez Del Pozo, J., Simo, A., Ureta, S. (1989): El Jurásico de Mallorca (Islas Baleares). Cuadernos de Geológia Ibérica, 13, 67-120

Amy, L.A., Talling, P.J. (2006): Anatomy of turbidites and linked debrites based on long distance $(120 \times 30 \mathrm{~km})$ bed correlation, Marnoso Arenacea Formation, Northern Apennines, Italy, Sedimentology 53 , 161-212. doi: 10.1111/j.1365-3091.2005.00756.x

Amy, P.J. Talling, J. Peakall, R.B. Wynn., Arzola Thynne, R. G. (2005): Bed geometry used to test recognition criteria of turbidites and (sandy) debrites. Sedimentary Geology 179, 163-174. doi: 10.1016/j.sedgeo.2005.04.007

Arbona, J., Fontboté, J., -M., González-Donoso, J., M., Linares, A., Oloriz, E., Pomar, L., Rivas, P., Sabat, E. (1984-1985): Precisiones biosestratrigráficas y aspectose sedimentológicos del Jurásico-Cretácico basal de la isla de Cabrera (Baleares). Cuadernos de Geología, Universidad de Granada 12, 169-186.

Arias, C. (2008): Palaeoceanography and biogeography in the Early Jurassic Panthalassa and Tethys Oceans. Gondwana Research 14 306315. doi:10.1016/j.gr.2008.03.004

Aurell, M., Meléndez, G., Bádenas, B., Pérez-Urresti, I., Ramajo, J. (2000): Sequence Stratigraphy of the Callovian-Berriasian (Middle Jurassic-Lower Cretaceous) of the Iberian basin (NE Spain). GeoResearch Forum 6, 281-292.

Azéma, J., Champetier, Y., Foucault, A., Fourcade, E., Rangheard, J. (1971): Le Jurassique dans le partie oriental des Zones Externes des Cordillères Bétiques: essai de coordination. Cuadernos de Geología Ibérica 2, 91-110.

Barnolas, A., Simo, A. (1987): La sedimentación oolítica del Dogger de Mallocra: Un modelo de bajada carbonática de pie de talud retrogradacional. Geogaceta 3 p31-34

Bell, C. M., Suárez, M. (1995): Slope apron deposits of the Lower Jurassic Los Molles Formation, Central Chile. Revista Geologica de Chile 22(1), p103-114

Bernoulli, D., Jenkyns, H.C. (1974): Alpine, Mediterranean and Central Atlantic Mesozoic facies in relation to the early evolution of the Tethys. In: R.H. Dott, R.H. Shaver, Editors, Modern and Ancient Geosynclinal Sedimentation, a Symposium, Special Publication Soc. econ. Paleont. Miner., 19, 129-160.

Blechschmidt, I., Dumitrica, P., Matter, A., Krystyn, L., Peters, T.J., 2004. Stratigraphic architecture of the northern Oman continental margin-Mesozoic Hamrat Dura Group, Hawasina complex, Oman. GeoArabia 9, 81-132

Brunet, M. F. (1986): The influence of the evolution of the Pyrenees on adjacent basins. Tectnophysics 129, 343-354

Bourroilh, R. (1973): Stratigraphie, sedimentology et tectonique de l'íle de Minorque et du Nord-East de Majorque (Baléares). La terminación nord-orentale des Cordillèras Bètiques en Mediterranée occidentale. PhD Thesis, Univeristy of Pierre and Marie Curie, Paris.

Cobianchi, M.,Picotti, V. (2001): Sedimentary and biological response 
to sea-level and palaeoceanographic changes of a Lower-Middle Jurassic Tethyan platform margin (Southern Alps, Italy). Palaeogeography, Palaeoclimatology, Palaeoecology 169(3-4), 219-244

Colacicchi., R., Baldanza, A. (1986): Carbonate turbidites in a Mesozoic pelagic basin: Scaglia Formation, Apennines. Comparison with siliciclastic depositional models. Sedimentary Geology 48, 81-105.

Colom, G.,Escandell, B. (1962): L'évolution du geosynclinals Baléare. Livre Mémoir. P. Fallot, Soc. Géol. France 1, 125-136.

Curnelle, R., Dubois, P., Seguin, J. C., Whitaker, D., Matthews, D. H., Roberts, D. G., Peter Kent, Laughton, A. S., Kholief M. M. (1982): The Mesozoic-Tertiary Evolution of the Aquitaine Basin. Philosophical Transactions of the Royal Society of London. Series A, Mathematical and Physical Sciences 305 (1489), 63-84 doi: 10.1098/ rsta.1982.0026

Dercourt, J., L.P. Zonenshain, L.-E. Ricou, V.G. Kazmin, X. Le Pichon, A.L. Knipper, C. Grandjacquet, I.M. Sbortshikov, J. Geyssant, C. Lepvrier, D.H. Pechersky, J. Boulin, J.-C. Sibuet, L.A. Savostin, O. Sorokhtin, M. Westphal, M.L. Bazhenov, J.P. Lauer, B. Biju-Duval. (1986): Geological evolution of the tethys belt from the atlantic to the pamirs since the Lias. Tectonophysics 123(1-4), 241-315 doi:10.1016/0040-1951(86)90199-X

Dutton, S. P., Kim, E. M., Broadhead, R. F. Breton, C. L., Raatz W. D., Ruppel S. C.,Kerans C. (2004): Play analysis and digital portfolio of major oil reservoirs in the Permian basin: Application and transfer of advanced geological and engineering technologies for incremental production opportunities: University of Texas at Austin, Bureau of Economic Geology, 408p.

Enos, P., Stephens, B. P. (1991): Basin-margin carbonates, mid-Cretaceous, Mexico. In: Bourrouilh, R.,Doyle, L. J. (eds). Carbonate Gravity Deposits. International Association of Sedimentologists, Special publication.

Felix, M., Leszczyński, S., Ślączka, A., Uchman, A., Amy, L., Peakall, J. (2009): Field expressions of the transformation of debris flows into turbidity currents, with examples from the Polish Carpathians and the French Maritime Alps. Marine and Petroleum Geology 26, 20112020 doi:10.1016/j.marpetgeo.2009.02.014

Flügel., F. (2004): Microfacies of Carbonate Rocks: Analysis, Interpretation and Application. Springer, 976p.

García-Hernandez, M., López-Garrido, A. C., Rivas, P., Sanz de Galdeno, C, Vera, J. A. (1980): Mesozoic palaeogeographic evolution of the External Zones of the Betic Cordillera. Geologie en Mijnbouw $59,155-168$

Golonka, J. (2007): Late Triassic and Early Jurassic palaeogeography of the world. Palaeogeography, Palaeoclimatology, Palaeoecology 244, 297-307 doi:10.1016/j.palaeo.2006.06.041

Gonzalez-Donoso, J. M, Linares, A., Lopez-Garrido, A. C., Vera, J. A. (1971): Bosquejo estratigráfico del Jurásico de las Cordilleras Béticas. Cuad Geol Iberica 2, 55-90

Goy, A., Martínez, G., Ureta, M. S. (1995): Ammonitina (Hammatoceratidae) of the Toarcian and Aalenian in the Serra de Llevant (Isle of Mallocra, Spain). Hantkeniana, 1, 97-104

Haughton, P. D. W. Barker S. P., McCaffrey, W. D. (2003): 'Linked' debrites in sand-rich turbidite systems - origin and significance. Sedimentology 50, 459-482. doi:10.1046/j.1365-3091.2003.00560.x

Hüneke, H.,Krienke, K. (2004): Toe-of-slope deposits of a Givetian reefrimmed platform: provenance of calcareous density-flow deposits (Rabat-Tiflet-Zone, Morocco). Facies 50 (2), 327-346. doi:10.1007/ s10347-004-0019-4

Janson, X., Kerans, C., Loucks, R., Marhx, M., A., Reyes, C., Murguia, F. (2011): Seismic architecture of a lower Cretaceous platform-toslope system, Santa Agueda and Poza Rica fields, Mexico. AAPG Bulletin. 95 (1), 105-146.

Kano, K.,Takeuchi, K. (1989): Origin of mudstone clasts in turbidites of the Miocene Ushikiri Formation, Shimane Peninsula, Southwest
Japan. Sedimentary Geology 62 79-87

Kessler, L.G., Moorhouse, K. (1984): Depositional processes and fluid mechanics of upper Jurassic conglomerate accumulations, British North Sea. In: Koster, E.H., Steel, R.J. (eds) Sedimentology of gravels and conglomerates. Canadian Society of Petroleum Geologists Memoir 10, 383-398.

Lagabrielle, Y., Polino, R., Auzende, J. -M., Blanchet, R., Caby, R., Fudral, S., Lemoine, M., Mevel, C., Ohnenstetter, M., Robert, D., Tricart, P. (1984): Les téoins d'une tectonique intra-océanique dans le domaine téthysien: analyse des rapports entre les ophiolites et leur converture métasédimentaire dans la zone piémontaise des Alpes framco-italiennes. Ofioliti 9, 67-88

Linares, A., Vera, J. A. (1966): Precisiones estratigráficas sobre la serie mesozoíca de Sierra Gorda, Cordilleras Beticas (provincial de Granada). Estudios geológicos XII, 65-99,

Lowe, D.R., (1982): Sediment gravity flows: II. Depositional models with special reference to the deposits of high-density turbidity currents, Journal of Sedimentary Petrology 52, 279-297.

Mamet, B.,Préat, A. (2006): Jurassic microfacies, Rosso Ammonitico limestone, Subbetic cordillera, Spain. Revista Española de Micropaleontología, 38(2-3), 19-228

Martin-Rojas, R. Somma, F. Delgado, A. Estévez, A. Iannace, Perrone, V.and Zamparelli, V. (2009): Triassic continental rifting of Pangaea: direct evidence from the Alpujarride carbonates, Betic Cordillera, SE Spain. Journal of the Geological Society 166, 447-458 doi: 10.1144/0016-76492008-091

Michard, A., Chalouan, A., Feinberg, H., Goffe, B., Montigny, R. (2002): How does the Alpine belt end between Spain and Morocco? Bulletin of the Geological Society of France 173 (1), 3-15 doi: 10.2113/173.1.3

Middleton, G. V.,Neal, W. J. (1989): Experiments on the thickness of beds deposited by turbidity currents. Journal of Sedimentary Petrology 59, 297-307 doi: 10.1306/212F8F7B-2B24-11D7-8648000102C1865D

Minero, C. J. (1991): Sedimentation and diagenesis along open and island-protected windward carbonate platform margins of the Cretaceous El Abra Formation, Mexico. Sedimentary Geology 71 (3-4), 261-288 doi:10.1016/0037-0738(91)90106-N

Mulder, T.,Alexander, J. (2001): The physical character of subaqueous sedimentary density flows and their deposits. Sedimentology 48, 269-299. doi: 10.1046/j.1365-3091.2001.00360.x

Mullins, H. T.,Cook, H. E. (1986): Carbonate apron models: Alternatives to the submarine fan model for palaeoenvironmental analysis and hydrocarbon exploration. Sedimentary Geology 48 37-79 doi:10.1016/0037-0738(86)90080-1

Mullins, H. T, Heath, K. C., Van Buren, H. M.,Newton, C. R. (1984): Anatomy of a modern open-ocean carbonate slope: Northern Little Bahama Bank. Sedimentology 31 141-168 doi: 10.1111/j.13653091.1984.tb01956.x

Navarro, V., Molina, J. M., Ruiz-Ortiz, P. S. (2009): Filament lumachelle on top of Middle Jurassic oolite limestones: event deposits marking the drowning of a Tethysian carbonate platform (Subbetic, southern Spain). Facies 55, 89-102

Noda, A., Toshimitsu, S. (2009): Backward stacking of submarine channel-fan successions controlled by strike-slip faulting: The Izumi Group (Cretaceous), southwest Japan. Lithosphere 1(1), 41-59 doi: 10.1130/L19.1

Olivero, D.,Gaillard, C. (1996): Palaeoecology of Jurassic Zoophycos from south-eastern France. Ichnos 4, 249-260 doi:10.1080/10420949609380135

Olóriz, F. (2000): Time averaging and long-term palaeoecology in macroinvertebrate fossil assemblages with ammonites (Upper Jurassic). Revue de Paléobiologie, Volume Spécial 8, 123-140

Phelps, R. M.,Kerans, C. (2007): Architectural characterisation and three-dimensional modelling of a carbonate channel-levee complex: Permian San-Andres Formation, Last Chance Canyon, New Mexico, 
USA. Journal of Sedimentary Research 77 (11-12), 939-964 doi: 10.2110/jsr.2007.085

Puga, E., Díaz de Federico, A., Molina-Palma, J. F., Nieto, J. M, Tendero-Segovia, J. A. (1993): Field trip to the Nevado-Filabride Complex (Betic Cordilleras, SE Spain). Ofioliti 18(1), 37-60.

Rivas, P. (1975): Calizas de flamentos en el Lias Medio de la Zona Subbética. Cuad Geol 6 p137-142

Rivas, P., Aguirre, J., Braga, J. C. (1997): Entolium beds: Hiatal shell concentrations in starved pelagic settings (Middle Liassic, SE Spain). Eclogae Geol Helv 90 p293-301

Ruiz-Ortiz, P. A., (1982): Estratificaciones cruzadas de gran escala en las calizas oolíticas de la Formación Jabalcuz (Dogger). Dominio Intermedio, Cordilleras Béticas. Acta Geologica Hispanica, 17 271-275

Sami, R., Soussi, M., Kamel, B., Kmar, B., Dorrik, S., Khomsi, S., Mourad, B. (2010): Stratigraphy, sedimentology and structure of the Numidian Flysch thrust belt in northern Tunisia, Journal of Af- rican Earth Sciences 57(1-2), p109-126 http://dx.doi.org/10.1016/j. jafrearsci.2009.07.016

Seilacher, A. (2007): Trace Fossil Analysis. Springer, 226p.

Stow, D. A. V., Pudsey, C. J., Howe, J. A., Faugères, J.-C., Viana, A. R. (eds). (2002): Deep-Water Contourite Systems: Modern Drifts and Ancient Series, Seismic and Sedimentary Characteristics. Geological Society, London, Memoirs 22, 289-303.

Vera, J. A. (1998): El Jurásico de la Cordillera Bética: Estado actual de conocimentos y problemas pendientes. Cuadernos de Geología Ibérica 24, 17-42

Wright, V.P., Wilson, R.C.L. (1984): A carbonate submarine fan sequence from the Jurassic of Portugal. Journal of Sedimentary Petrology 54/2, 394-412. doi: 10.1306/212F8427-2B24-11D7-8648000102C1865D

Ziegler, P. A. (1990): Geological atlas of western and central Europe. Shell Internationale Petroleum Maastschappij BV, International Lithosphere Program 148, p239

ONLINE SUPPLEMETARY MATERIAL

www. http://revistas.ucm.es/index.php/JIGE

Appendix

Stratigraphic logs 